\title{
Drainage reorganization and divide migration induced by the excavation of the Ebro basin (NE Spain)
}

\author{
Arnaud Vacherat, Stéphane Bonnet, and Frédéric Mouthereau \\ Géosciences Environnement Toulouse (GET), Université de Toulouse, CNRS, IRD, UPS, Toulouse, France \\ Correspondence: Stéphane Bonnet (stephane.bonnet@get.omp.eu)
}

Received: 6 September 2017 - Discussion started: 12 October 2017

Revised: 19 March 2018 - Accepted: 11 April 2018 - Published: 14 May 2018

\begin{abstract}
Intracontinental endorheic basins are key elements of source-to-sink systems as they preserve sediments eroded from the surrounding catchments. Drainage reorganization in such a basin in response to changing boundary conditions has strong implications on the sediment routing system and on landscape evolution. The Ebro and Duero basins represent two foreland basins, which developed in response to the growth of surrounding compressional orogens, the Pyrenees and the Cantabrian mountains to the north, the Iberian Ranges to the south, and the Catalan Coastal Range to the east. They were once connected as endorheic basins in the early Oligocene. By the end of the Miocene, new post-orogenic conditions led to the current setting in which the Ebro and Duero basins are flowing in opposite directions, towards the Mediterranean Sea and the Atlantic Ocean. Although these two hydrographic basins recorded a similar history, they are characterized by very different morphologic features. The Ebro basin is highly excavated, whereas relicts of the endorheic stage are very well preserved in the Duero basin. The contrasting morphological preservation of the endorheic stage represents an ideal natural laboratory to study the drivers (internal and/or external) of post-orogenic drainage divide mobility, drainage network, and landscape evolution. To that aim, we use field and map observations and we apply the $\chi$ analysis of river profiles along the divide between the Ebro and Duero drainage basins. We show here that the contrasting excavation of the Ebro and Duero basins drives a reorganization of their drainage network through a series of captures, which resulted in the southwestward migration of their main drainage divide. Fluvial captures have a strong impact on drainage areas, fluxes, and their respective incision capacity. We conclude that drainage reorganization driven by the capture of the Duero basin rivers by the Ebro drainage system explains the first-order preservation of endorheic stage remnants in the Duero basin, due to drainage area loss, independently from tectonics and climate.
\end{abstract}

Landscapes subjected to contrasted erosion rates between adjacent drainage basins show a migration of their drainage divide toward the area of lower erosion rates (Bonnet, 2009; Willett et al., 2014). This is the case for mountain ranges characterized by gradients in precipitation rates due to orography, once landscapes are in a transient state and are not adjusted to precipitation differences (Bonnet, 2009). It also occurs when drainage was reorganized in response to capture (Yanites et al., 2013; Willett et al., 2014). River capture actually drives a drop in the spatial position of drainage divide (Prince et al., 2011) but also produces a wave of erosion in the captured reach (Yanites et al., 2013) that may impact divide position. Historically, migration of divides has been inferred by changes in the provenance of sediments stored in sedimentary basins (e.g., Kuhlemann et al., 2001). It is however a process that is generally very difficult to document in erosional landscapes. Recent developments have provided models and analytical approaches to identify divide migration in the landscape (Bonnet, 2009; Castelltort et al., 2012; Willett et al., 2014; Whipple et al., 2017). Among them the recently developed $\chi$ analysis of longitudinal profiles of rivers (Perron and Royden, 2012) is based on the recognition of disequilibrium along river profiles, disequilibrium being defined by the departure from an ideal equilibrium shape. 
The application of this method to both natural and numerically simulated landscapes has allowed us to demonstrate contrasts in the equilibrium state of rivers across divide and then to infer their migration (Willett et al., 2014). The applicability of this method is however limited to settings where the response time of rivers is larger compared to the rate of divide migration, so they can actually show disequilibrium in their longitudinal profiles (Whipple et al., 2017).

The Ebro and Duero drainage basins in the northern Iberian Peninsula show geological and geomorphological evidence of very contrasted erosional histories during the Neogene. They initially recorded a long endorheic stage from the early Oligocene to the late Miocene (Riba et al., 1983; Garcia-Castellanos et al., 2003). Since then, both basins opened toward the Atlantic Ocean (Duero) or the Mediterranean Sea (Ebro). The Ebro basin's opening is reflected in the landscape by evidence of river incision (GarciaCastellanos et al., 2003), whereas the Duero basin does not show significant incision in its upstream part as a large relict of its endorheic morphology is preserved (Antón et al., 2012). The Duero River long profile actually shows a pronounced knickpoint (knickzone) defining an upstream domain of high mean elevation $(\sim 800 \mathrm{~m})$ and low relief where the sediments deposited during the endorheic stage are relatively well preserved. Then, these two adjacent basins are characterized by differences in incision and in the preservation of their endorheic stages. They thus represent an ideal natural laboratory to evaluate divide migration in response to differential post-orogenic incision. Following a presentation of the geological context, we first compile evidence of fluvial captures along the Ebro-Duero divide, based on previous studies and our own investigations, and we map the location of knickpoints and relict portions of the drainage network. We use all these observations to reconstruct a paleo-divide position and to estimate the impact of divide migration in terms of drainage area and stream power. We complement this dataset by providing a map of $\chi$ across divide (Willett et al., 2014) to highlight the potential disequilibrium state between rivers of the Ebro and Duero catchments.

\section{Geological setting}

\subsection{The Ebro and Duero basins}

The Ebro and Duero basins represent two hydrographic basins located in the northern part of the Iberian Peninsula (Fig. 1). The bedrock of the Ebro and Duero drainage basins mainly consists of Cenozoic deposits, and Mesozoic and Paleozoic rocks in their headwaters (Fig. 2). They once formed a unique flexural foreland basin during the Cenozoic controlled by the surrounding mountain belts: the Pyrenees and the Cantabrian mountains to the north (Pulgar et al., 1999), the Iberian and Central ranges to the south (Guimerà et al., 2004; De Vicente et al., 2007), and the Catalan Coastal Range (CCR) to the east (López-Blanco et al., 2000; Salas et al., 2001), during collision between Iberia and Europe since the Late Cretaceous.

From the Late Cretaceous, the Ebro and Duero basins were essentially filled by clastic deposits, and opened toward the Atlantic Ocean in the Bay of Biscay (Alonso-Zarza et al., 2002). During the late Eocene-early Oligocene, the uplift in the Western Pyrenees (Puigdefàbregas et al., 1992) led to the closure of the Ebro and Duero basins as attested by the Ebro basin continentalization dated at $\sim 36 \mathrm{Ma}$ (Costa et al., 2010). The center of these two basins became longlived lakes filled with lacustrine, sandy, and evaporitic deposits from the Oligocene to the Miocene (Riba et al., 1983; Alonso-Zarza et al., 2002; Pérez-Rivarés et al., 2002, 2004; Garcia-Castellanos et al., 2003; Garcia-Castellanos, 2006; Larrasoaña et al., 2006; Vázquez-Urbez et al., 2013). The opening of the Ebro basin through the CCR toward the Mediterranean Sea occurred during the late Miocene, leading to kilometer-scale excavation throughout the basin (Fillon and Van der Beek, 2012; Fillon et al., 2013; GarciaCastellanos and Larrasoaña, 2015). The exact timing and processes driving the opening, as well as the role of the Messinian Salinity Crisis, has long been debated (Coney et al., 1996 (post-Messinian); Garcia-Castellanos et al., 2003 (13-8.5 Ma); Babault et al., 2006 (post-Messinian); Urgeles et al., 2010; Cameselle et al., 2014 (Serravallian-Tortonian); Garcia-Castellanos and Larrasoaña, 2015 (12-7.5 Ma)). In contrast with the Ebro basin, incision in the upper Duero basin appears much less significant. The Duero basin is characterized by a low-relief topography (Fig. 1) in its upstream part, at 700-800 ma.s.l. to the west, and at 1000 $1100 \mathrm{~m}$ a.s.l. to the north, northeast, and to the east in the Almazán subbasin, close to the divide with the Ebro basin. The connection of the Duero River with the Atlantic Ocean occurred from the late Miocene-early Pliocene to the late Pliocene-Early Pleistocene (Martín-Serrano, 1991). The current Ebro and Duero drainage networks are separated by a divide running from the Cantabrian belt to the NW, toward the SE in the Iberian Range (Figs. 1-3). In the following, we review the geological evolution of the different domains that constitute this drainage divide between the Ebro and Duero drainage basins.

\subsection{The Iberian Range}

The Iberian Range (Figs. 2 and 4) is a double vergent foldand-thrust belt resulting from Late Cretaceous inversion of Late Jurassic-Early Cretaceous rift basins during IberiaEurope convergence (Salas et al., 2001; Guimerà et al., 2004; Martín-Chivelet et al., 2002). It is divided into two NW-SEdirected branches, the Aragonese and the Castilian branches, separated by the Tertiary Almazán subbasin (Bond, 1996). The Almazán subbasin has been connected to the Duero basin since the early Miocene (Alonso-Zarza et al., 2002).

The Iberian Range is essentially made of marine carbonates and continental clastic sediments ranging from late 

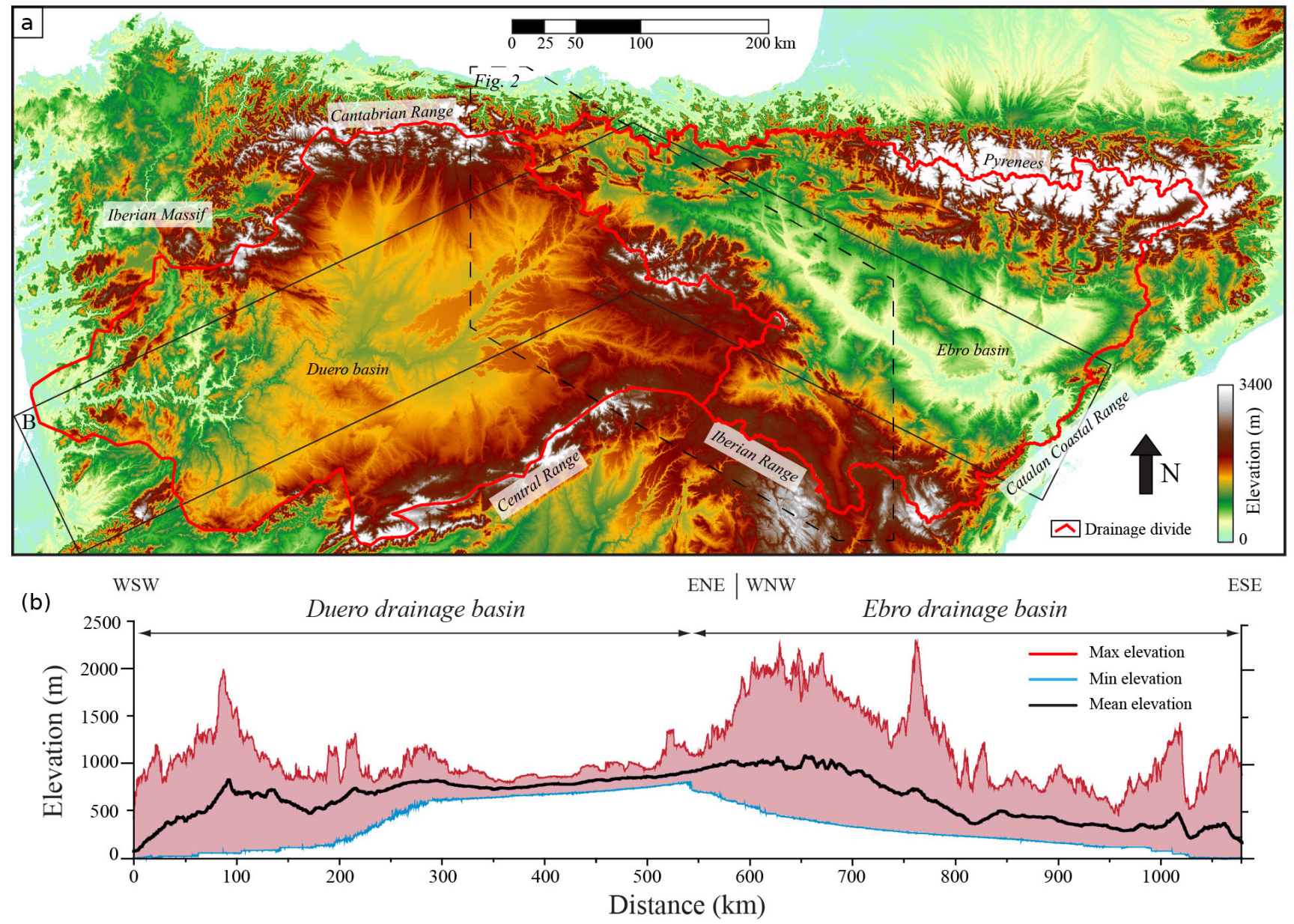

Figure 1. (a) Topographic map of the Duero and Ebro basins and surrounding belts. (b) Averaged topographic section throughout the Duero and Ebro basins showing important incision contrast between the two basins. The Duero basin recorded low incision, especially in its upper part, whereas the Ebro basin is highly excavated.

Permian to Albian, overlying a Hercynian basement. The Cameros subbasin to the NW represents a Late JurassicEarly Cretaceous trough almost exclusively filled by continental siliciclastic deposits (Martín-Chivelet et al., 2002 and references therein; Del Rio et al., 2009). Shortening in the Iberian Range occurred from the Late Cretaceous to the early Miocene, along inherited Hercynian NW-SE structures (Gutiérrez-Elorza and Gracia, 1997; Guimerà et al., 2004; Gutiérrez-Elorza et al., 2002). The opening of the Calatayud basin in the Aragonese branch occurred during the Early Miocene in response to right-lateral transpression on the southern margin of the Iberian Range (Daroca area) (Colomer and Santanach, 1988). It is followed during the Pliocene and the Pleistocene by pulses of extensionreactivating faults in the Calatayud basin and the formation of grabens such as the Daroca, Munébrega, Gallocanta, and Jiloca grabens (Fig. 4; Colomer and Santanach, 1988; Gutiérrez-Elorza et al., 2002; Capote et al., 2002). This is also outlined by the occurrence of late Pliocene to
Early Pleistocene breccias and glacis levels in the Daroca and Jiloca grabens (Gracia, 1992, 1993a; Gracia and Cuchi, 1993; Gutiérrez-Santolalla et al., 1996). These Neogene troughs are filled by continental deposits and pediments, up to the Quaternary (Fig. 4). The Neogene tectonic pulses in the Iberian are interrupted by periods of quiescence during which erosion surfaces developed (Gutiérrez-Elorza and Gracia, 1997).

Deformation and uplift of the Iberian Range and Cameros basin resulted in the development of a new drainage divide between the Duero and Ebro basins and in the isolation of the Almazán subbasin (Alonso-Zarza et al., 2002). In contrast, the connection between the Duero and Ebro basins has not been affected by significant deformation and uplift in the proto-Rioja trough (Mikes, 2010).

\subsection{The Rioja trough and Bureba high}

The Rioja trough (Figs. 2 and 5) recorded important subsidence, especially during the Cenozoic ( $>5 \mathrm{~km}$ ), related to 


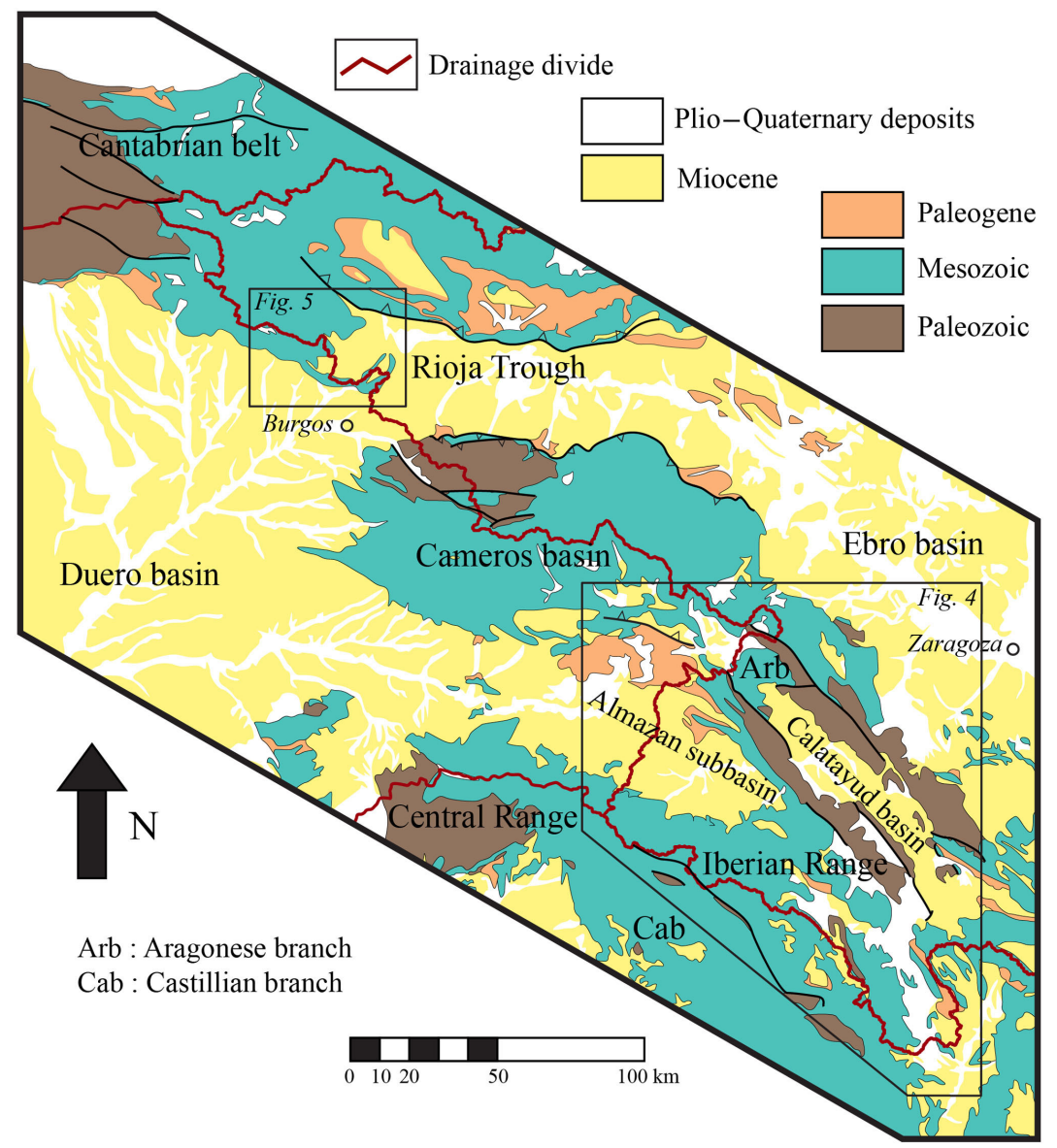

Figure 2. Simplified geological map of the study area.

compression and thrusting on its borders (Jurado and Riba, 1996). As thrusting initiated in the Pyrenean-Cantabrian belt and in the Iberian Range and Cameros basin, the Rioja trough became domain of important synorogenic sediment transfer between the Ebro and Duero basins. During the Paleocene, the Rioja trough was a marine depositional environment. With the increase in sediment fluxes that originated from the exhumation of surrounding mountain bets, sedimentation became essentially continental in the Eocene. Thrusting continued during the Oligocene, resulting in the formation of an anticline connecting the Cantabrian domain and the Cameros inverted basin. This morphologic high (the Bureba anticline, Fig. 5) located in the center of the area is supposed to have triggered the disconnection between the Duero and Ebro basins (Mikes, 2010), as suggested by the repartition of alluvial fans on both sides of this structure (MuñozJiménez and Casas-Sainz, 1997; Villena et al., 1996). During the Miocene, deformation ceased as evidenced by the deposition of undeformed middle Miocene to Holocene strata. The Bureba anticline is cored by Albian strata and topped by Santonian limestones and Oligocene conglomerates controlling the location of the current main drainage divide between the Ebro and Duero river networks (Fig. 5).

\subsection{Climate evolution}

Climate exerts a major control on valley incision, sediment discharge, and on the evolution of drainage networks (Willet, 1999; Garcia-Castellanos, 2006; Bonnet, 2009; Whipple, 2009; Whitfield and Harvey, 2012; Stange et al., 2014). The mean annual precipitation map for the northern Iberian Peninsula (Hijmans et al., 2005) shows a similar pattern for both the Ebro and Duero basins as they record very low precipitation, associated with global subarid conditions, with the exception of the Cameros basin, which records a slightly higher precipitation rate (Fig. 6). There is a strong contrast to the north, toward the Mediterranean Sea and the most elevated areas in the Cantabrian and Pyrenean belts, where precipitation drastically increases.

The paleoclimatic evolution from the Late Cretaceous to the Neogene is linked with both the effects of surrounding mountain uplift, and with the latitudinal variation drift of Iberia from $30^{\circ} \mathrm{N}$ in the Cretaceous to $\sim 40^{\circ} \mathrm{N}$ during late Neogene times. The hot-humid tropical climate of the Late 


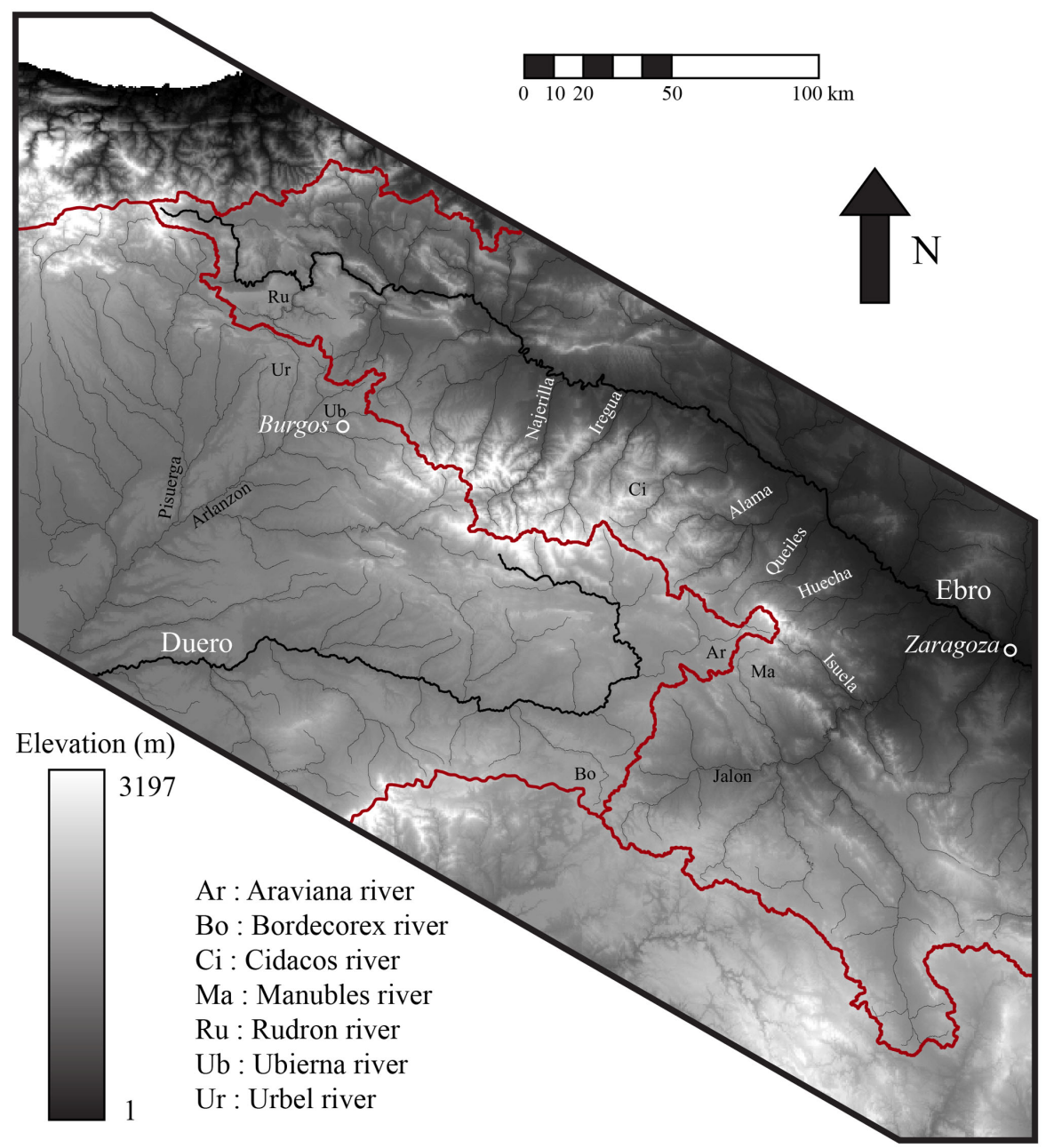

Figure 3. Topographic map of the study area with all the rivers considered in this study. The red lines represent drainage divides between main hydrographic basins.

Cretaceous became drier and arid from the Paleocene to the middle Miocene (López-Martínez et al., 1986), favoring the development of endorheic lakes (Garcia-Castellanos, 2006). During the middle-late Miocene and early Pliocene, the northern Iberia recorded more humid and seasonal conditions (Calvo et al., 1993; Alonso-Zarza and Calvo, 2000) with alternations of cold-wet and hot-dry periods (Bessais and Cravatte, 1988; Rivas-Carballo et al., 1994; Jiménez-Moreno et al., 2010). More humid and colder conditions took place in the late Pliocene, characterized by dry glacial periods and humid interglacials (Suc and Popescu, 2005; Jiménez-Moreno et al., 2013). Climatic contrasts increased, triggering intense glacier fluctuations in the surrounding mountain ranges during the Lower-Middle Pleistocene transition (1.4-0.8 Ma) (Moreno et al., 2012; Duval et al., 2015; Sancho et al., 2016), and throughout the Late Pleistocene period, which record glacial-interglacial oscillations, as evidenced by pollen identification (Suc and Popescu, 2005; Jiménez-Moreno et al., 2010, 2013; Barrón et al., 2016; García-Ruiz et al., 2016) and speleothem studies (Moreno et al., 2013; Bartolomé et al., 2015).

Glaciers are considered a very efficient erosion tool in a continental environment. They are likely to influence drainage divide migration (Brocklehurst and Whipple, 2002). There is large evidence of glacier development, especially for the Late Pleistocene in the Pyrenees (Delmas et al., 2009; Nivière et al., 2016; García-Ruiz et al., 2016), in the Cantabrian belt (Serrano et al., 2013, 2016; García-Ruiz et al., 2016), and in the Central Range (Palacios et al., 2011, 2012; García-Ruiz et al., 2016). However, although numerous moraines have been mapped throughout the Iberian Range (Ortigosa, 1994; García-Ruiz et al., 1998; Pellicer and Echeverría, 2004), there is no evidence of U-shaped valleys and because of the lack of very highly elevated massifs $(>2500 \mathrm{~m})$, the occurrence of active ice tongues is considered limited, if not precluded (García-Ruiz et al., 2016). 

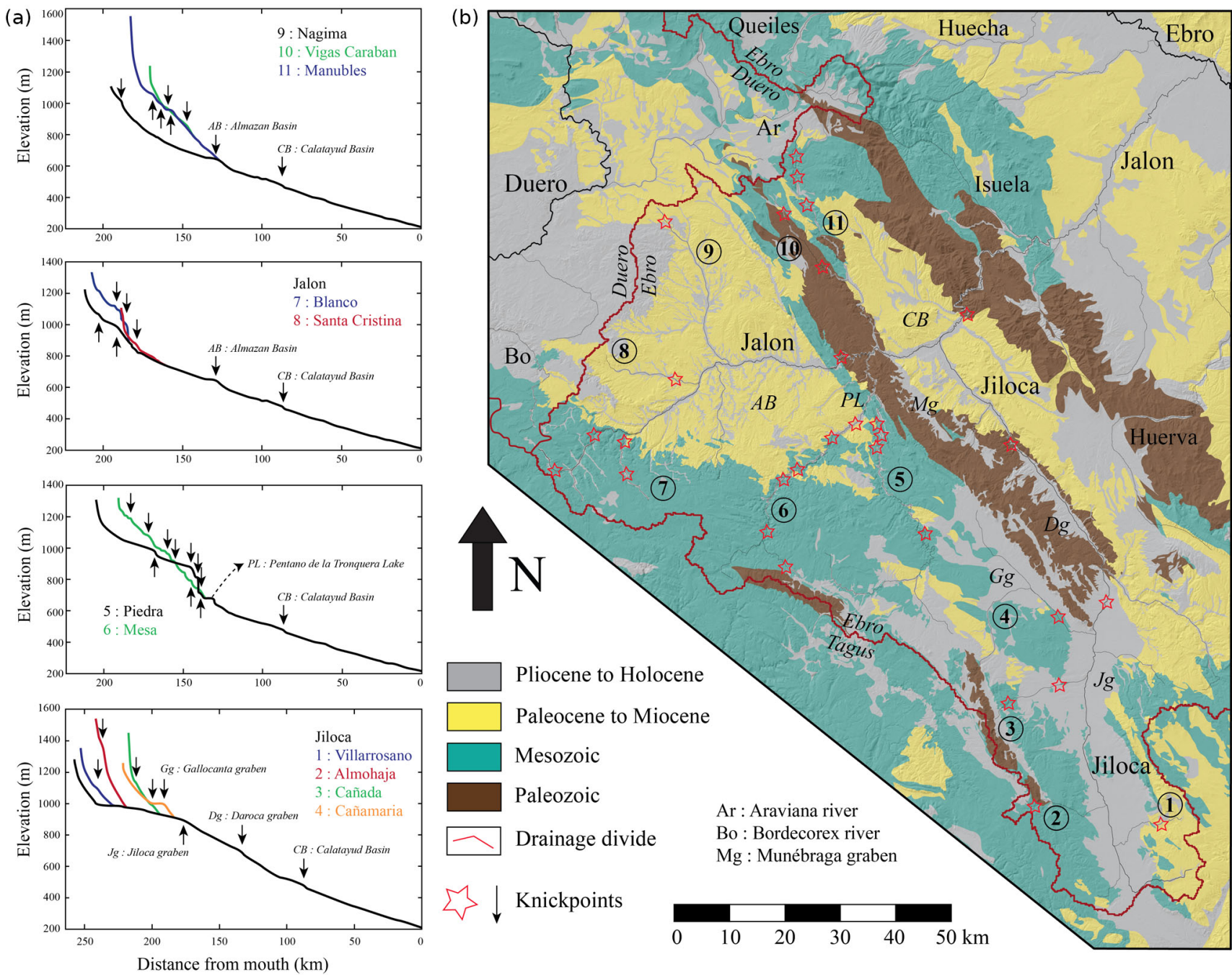

Figure 4. Zoom of the geological map of the Iberian Range showing the location of the Jalón River tributaries. The river long profiles of these streams and the location of knickpoints are shown to the left.

\section{Evidence of divide mobility between the Duero and Ebro catchments}

The easternmost part of the Duero River is opposed to the Ebro tributaries that are the Jalón, Huecha, Queiles, Alama, Cidacos, Iregua, and Najerilla rivers, whereas the Arlanzón and Pisuerga rivers (Duero tributaries) are opposed to the Najerilla, Tirón, Oca, and Rudrón rivers, and to the westernmost part of the Ebro River (Fig. 3). The northeastern part of the Duero basin (the easternmost Duero River, the Arlanzón and Pisuerga rivers) mainly consists of broad flat valleys characterized by low incision depth and low-gradient streams with concave longitudinal profiles (Antón et al., 2012, 2014). By contrast, the western part of the Ebro basin is characterized by more incised valleys, especially in the Cantabrian and in the Cameros-Iberian Range domains, with more complex longitudinal profiles (knickpoints, remnants of highly ele- vated surfaces). Previous studies (Gutiérrez-Santolalla et al., 1996; Pineda, 1997; Mikes, 2010) have already shown that the Jalón and Homino rivers, which belong to the Ebro basin, have recently captured parts of the Duero basin in the Iberian Range and in the Rioja trough, respectively. Such evolution has been recorded by the occurrence of geomorphological markers as wind gaps and elbows of captures, as well as by the presence of knickpoints and/or remnants of highly elevated surfaces in river long profiles. To highlight this dynamic evolution, we performed a morphometric analysis of rivers all around the divide separating the Ebro basin from the Duero basin, with particular attention given to the Aragonese branch of the Iberian Range (Fig. 4) and to the Rioja trough (Fig. 5), where captures have already been described.

The studied basins were digitally mapped using highresolution $(\sim 30 \mathrm{~m})$ digital elevation models (DEMs) from SRTM 1 arcsec global elevation data available at the US Geo- 

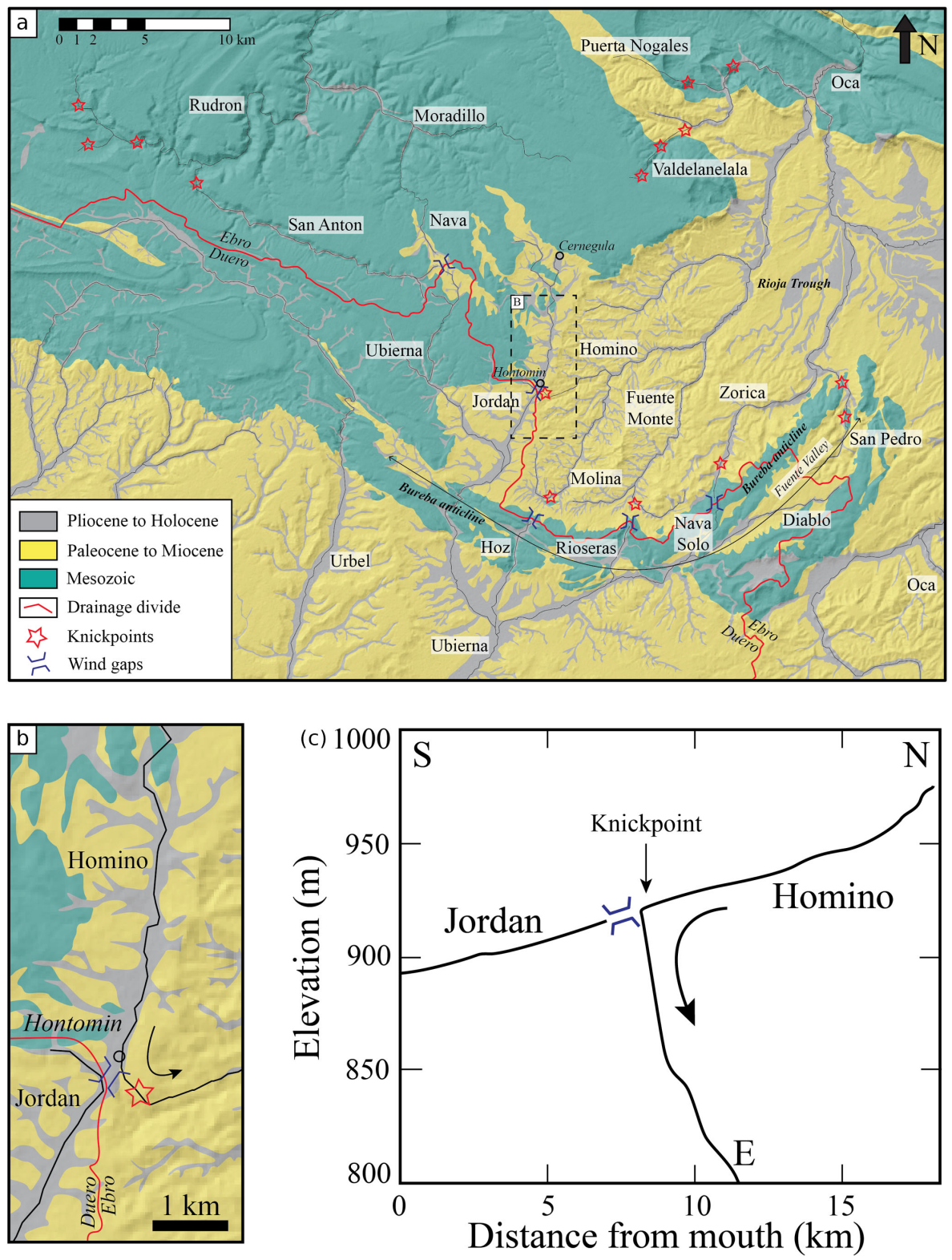

Figure 5. (a) Zoom of the geological map of the Bureba sector. (b) Zoom of the Homino River (Ebro tributary) capturing the upper reach of the Jordan River (Duero tributary). (c) Schematic representation of this capture using river long profiles and map orientation, showing the associated knickpoint and wind gap.

logical Survey (www.usgs.gov, last access: 5 May 2018). The different DEMs were assembled using the ENVI software. We also used 1:50000 geological maps from the Instituto Géologico y Minero de España (www.igme.es, last access: 5 May 2018). We used the TopoToolbox, a MATLAB-based software developed by Schwanghart and Scherler (2014), to extract the river network and longitudinal profiles and the $\chi$ analysis tool developed by Mudd et al. (2014).

\subsection{Fluvial captures and related knickpoints in the Iberian Range}

Neogene tectonics in the Iberian range controlled the uplift of topographic ranges and the formation of several basins whose connection with the Ebro or the Duero has occasionally changed through time. Today, the western part of the Almazán subbasin (Figs. 2 and 4) belongs to the Duero catchment, its eastern part being drained by the Ebro drainage network and especially by the Jalón River and its tributaries (Fig. 4). Gutiérrez-Santolalla et al. (1996) proposed that the 
Jalón River captured this domain after cutting into the Mesozoic and Neogene strata and the two Paleozoic ridges of the Aragonese branch of the Iberian Range. They used chronostratigraphic evidence to build a relative chronology of capture events in the Jalón area. First, the incision of the northern Paleozoic ridge and capture of the Calatayud basin by the Jalón River is attributed to a post-Messinian age. The Jiloca River, the easternmost main Jalón tributary, is then thought to capture the Daroca graben area to the east during the late Pliocene-Early Pleistocene. This is followed from the Early to Late Pleistocene by the capture of the Jiloca graben to the southeast and finally by the capture of the Munébrega graben to the southwest, by the Jalón River (Gutierrez-Santolalla et al., 1996), toward the easternmost part of the Almazán subbasin.

The Jalón River and tributaries show knickpoints in their longitudinal profiles (Fig. 4), at locations that are consistent with the events of captures proposed by Gutiérrez-Santolalla et al. (1996), suggesting that these captures are actually witnessed by knickpoints. The capture of the Jiloca graben corresponds to a major knickpoint in the Jiloca River profile that appears very smoothed, and that is followed by an upstream $\sim 50 \mathrm{~km}$ long flat domain preserved at $\sim 1000 \mathrm{~m}$ a.s.l. This imparts a convex shape to the Jiloca profile (Fig. 4). Due to the short period of time between the formation of the Jiloca graben (the earliest glacis deposits are attributed to the middle Pliocene) and its capture (Early Pleistocene; GutierrezSantolalla et al., 1996), we suggest this upstream domain was a short-lived endorheic domain that has never been externally drained before being captured by the Ebro network. In the northwestern part of the Jiloca graben, the Cañamaria River, a tributary of the Jiloca River, heads to the northwest, reaching the Gallocanta basin, also considered a former graben (Gracia, 1993b; Gracia et al., 1999; Gutiérrez-Elorza et al., 2002). The upstream part of its river long profile is characterized by a sharper knickpoint at the entrance of the basin and is followed by a $\sim 15 \mathrm{~km}$ long flat domain (Fig. 4). Similar to the Jiloca graben, the Gallocanta basin appears to be a short-lived endorheic domain that has been more recently captured by the Jiloca River network.

According to Gutiérrez-Santolalla et al. (1996), the Jalón River reached the southern Paleozoic ridge of the Aragonese branch, to the southwest of the Calatayud basin, and captured the Munébrega graben and the Almazán subbasin (also characterized by a pronounced knickpoint) during the Pleistocene-Holocene, slightly after the capture of the Jiloca graben by the Jiloca River. This is coherent with morphological analysis of longitudinal profiles, as the major knickpoint related to the capture of the Jiloca graben appears very smoothed, whereas knickpoints observed in the west are sharper, suggesting they are younger. However we cannot rule out some local influence of the lithology on the shape of these knickpoints.

Finally, the Piedra River (Jalón tributary) long profile shows major sharp knickpoints and two successive $\sim 30 \mathrm{~km}$ long almost flat domains in the Almazán subbasin, at 9001000 ma.s.l. (Fig. 4). In addition, the upper reach of the river long profiles of the Jalón River, and of its tributary the Blanco River, are characterized by major sharp knickpoints, and by a $\sim 15 \mathrm{~km}$ long flat domain at $\sim 1000-1100$ ma.s.l., in the Mesozoic Castilian branch of the Iberian Range (Fig. 4).

\subsection{Fluvial captures and related knickpoints in the Rioja trough area}

In the Rioja trough area, the position of the Ebro-Duero divide is partly controlled by the Bureba anticline. It consists of folded Middle Cretaceous to early Miocene series, covered by undeformed middle Miocene to Holocene deposits (Fig. 5). The anticline is orientated E-W to the west and NE-SW to the east. The western part of the Rioja trough to the west of the NE-SW-directed branch of the Bureba anticline (Fig. 5) used to be drained toward the Duero basin since the Oligocene (Pineda, 1997; Mikes, 2010). The westward migration of the divide to its current location is thought to have occurred in several steps of captures as shown by the occurrence of remnants of escarpments during the late Miocene-Pliocene (Mikes, 2010). Once the eastern branch of the Bureba anticline has been incised, the Ebro tributaries captured the western part of the Rioja trough, up to the EW branch of the Bureba anticline to the southwest, from the late Miocene to the Pliocene. The western part of the anticline forms a topographic ridge that is incised by the Jordan River (Fig. 5) in a place where the divide between the Ebro and Duero river networks is located to the north of the ridge. To the east of this location, however, the topographic ridge formed by the Bureba anticline controls the current location of the main drainage divide (Fig. 5). Here, the ridge exhibits several wind gaps, located on the northward prolongation of the Hoz, Rioseras, and Nava Solo rivers (Figs. 5 and 7). Further east, the Diablo River does not incise the ridge and its headwater is located in the core of the eastern branch of the Bureba anticline, the Fuente Valley (Fig. 5). These last streams are tributaries of the Ubierna River, which is a tributary of the Arlanzón River and so, of the Duero River. To the north, the Ebro River system is represented, from west to east, by the Homino River (a tributary of the Oca River) and its four tributaries, the Molina, the Fuente Monte, the Zorica, and the San Pedro rivers (Figs. 5 and 7). All these streams are outlined by Late Pleistocene to Holocene alluvial series that are deposited at the bottom of their respective valleys. Valleys from the Duero side appear larger than those from the Ebro side, which are significantly more incised.

The Jordan River's headwater is located north of the ridge formed by the Bureba anticline. We can continuously follow its valley deposits northward along a broadly gentle slope, up to the locality of Cornégula (Fig. 5). However, the current course of the Jordan River is cut $\sim 8 \mathrm{~km}$ south, in the vicinity of Hontomin, by the Homino (Ebro) River (Figs. 5b, c, and 7). This fluvial capture is characterized by a well-defined 
and highly incised elbow of capture, already described by Pineda (1997) and Mikes (2010). The longitudinal profile of the Homino River shows a sharp knickpoint located on Hontomin (Fig. 7c). Finally, there is a small wind gap on the divide between the two opposite rivers (Figs. 5 and 7).

To the southeast, the headwater of the Hoz River is located to the south of a wind gap cut into the Bureba ridge (Fig. 7c). To the north, in the exact prolongation of the Hoz River, the Molina River shows a bend similar to the elbow of capture previously described for the Homino River (Fig. 7) and there is a minor knickpoint located on this elbow, according to the extracted river long profile. Thus, it is likely that the Molina River used to represent the former upper reach of the Hoz River, in a period when the Ebro-Duero divide was located northward, before being captured by the Ebro network.

To the east, the Rioseras and the Nava Solo rivers also have their headwaters located to the south of wind gaps in the $\mathrm{Bu}$ reba ridge (Fig. 7). Similarly, in their exact prolongations, the Fuente Monte and the Zorica rivers show important elbows of capture with minor knickpoints. They may also represent former upper reaches of Duero streams that have been captured by the Ebro network (Figs. 5, 7 and 8).

Further east, the headwater of the Diablo River is located on the depression represented by the core of the eastern branch of the Bureba anticline, the Fuente valley. In its prolongation to the northeast, the San Pedro River incises the northeastern termination of the anticline from the north before entering the valley, leading to a southward retreat of the divide (Fig. 5). Capture is again evidenced by important incision contrast between the Ebro and Duero systems and by sharp knickpoints on the upper reach of the San Pedro River long profile when crossing the Santonian dolomites (Fig. 8). According to this whole set of observations, and in agreement with previous findings of Pineda (1997) and Mikes (2010), we propose that the western part of the Rioja trough in the Bureba area has been recently captured by the Ebro drainage network, leading to a sequence of southwestward retreat of the main drainage divide toward the Duero basin (Fig. 7e).

A similar capture pattern can be observed further west in the continuity of the Bureba anticline (Fig. 5). The San Anton River shows a well-defined elbow of capture accompanied by a smoothed knickpoint (See Fig. S1 in the Supplement) at its junction with the Rudrón River (Ebro tributary). The river course is highly incised toward the east, along the northern flank of the WNW-ESE anticline, almost connecting to the upper reach of the Ubierna River. Valley deposits are also observed in the continuity of the Ubierna valley, the former route of which is suggested by a wind gap (Fig. 5). However, this domain is no longer connected to its network as it is now wandered from the north by the Nava River, a tributary of the Moradillo River, which is a tributary of the Rudrón River. This domain clearly records captures leading to divide migration toward the Duero, also in favor of the Ebro basin.

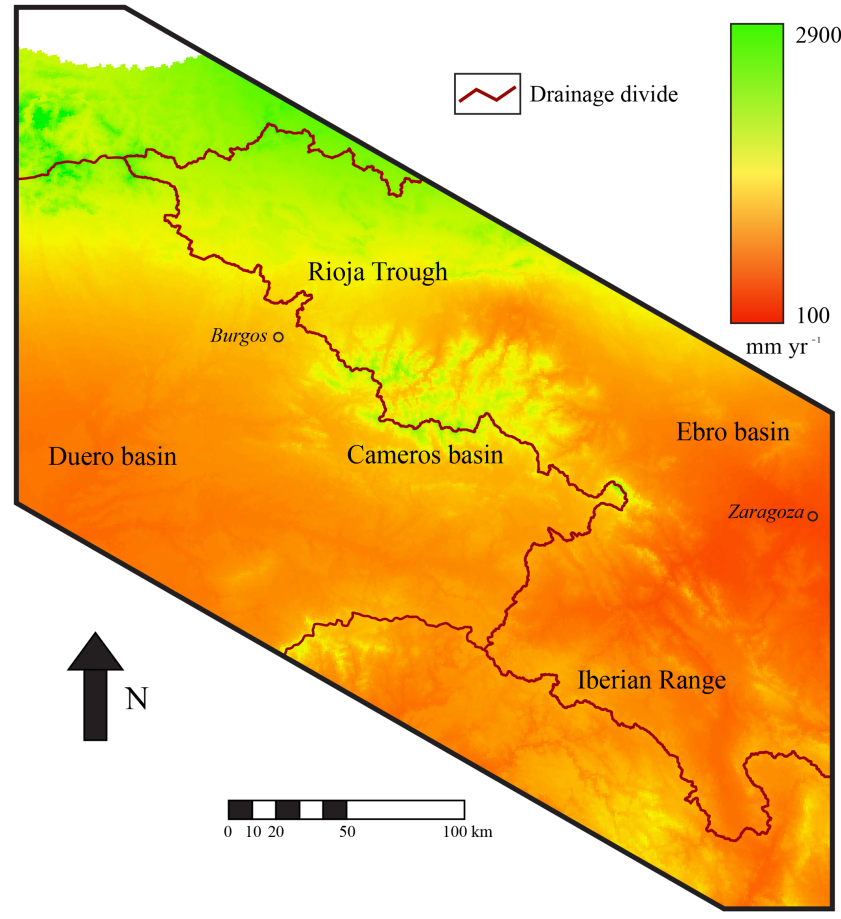

Figure 6. Mean annual precipitation map for the study area (data from Hijmans et al., 2005).

\subsection{Past position of the Ebro-Duero divide and implication for stream power of the Duero River}

We used all observations that support divide migration in the Iberian Range and Rioja trough to estimate a paleo-position of the drainage divide between the Duero and Ebro drainage basins (Fig. 9). For this purpose, we considered the location of major knickpoints along the rivers where fluvial captures are defined. Both the Ebro River and several tributaries show highly elevated $\sim 10-20 \mathrm{~km}$ long flat domains at $\sim 800$ 1200 ma.s.l. and major knickpoints in the upper reach of their long profiles like the Rudrón, Queiles, and Alama rivers, as well as the Homino River and its tributaries: the Puerta Nogales and Valdelanelala rivers (Figs. 5 and 8; Fig. S1). All these flat domains may not be related to surface uplift as they are not clearly associated with active tectonic features. With the Duero basin being characterized by a high mean elevation $(\sim 1000 \mathrm{~m})$ and by a very limited incision in the vicinity of the Ebro-Duero drainage divide, a sudden divide migration toward the Duero basin is then expected to isolate such highly elevated and relatively preserved surfaces. We suggest these flat domains have been recently captured by Ebro tributaries, and represent remnants of Duero drainage areas, integrated into the Ebro catchment from divide retreat toward the Duero basin. Overall, we consider a paleodrainage divide delimited by these high-elevated knickpoints and flat domains, except for the Jiloca graben area to the southeast, characterized by the occurrence of short-lived endorheic domains (Fig. 9). 

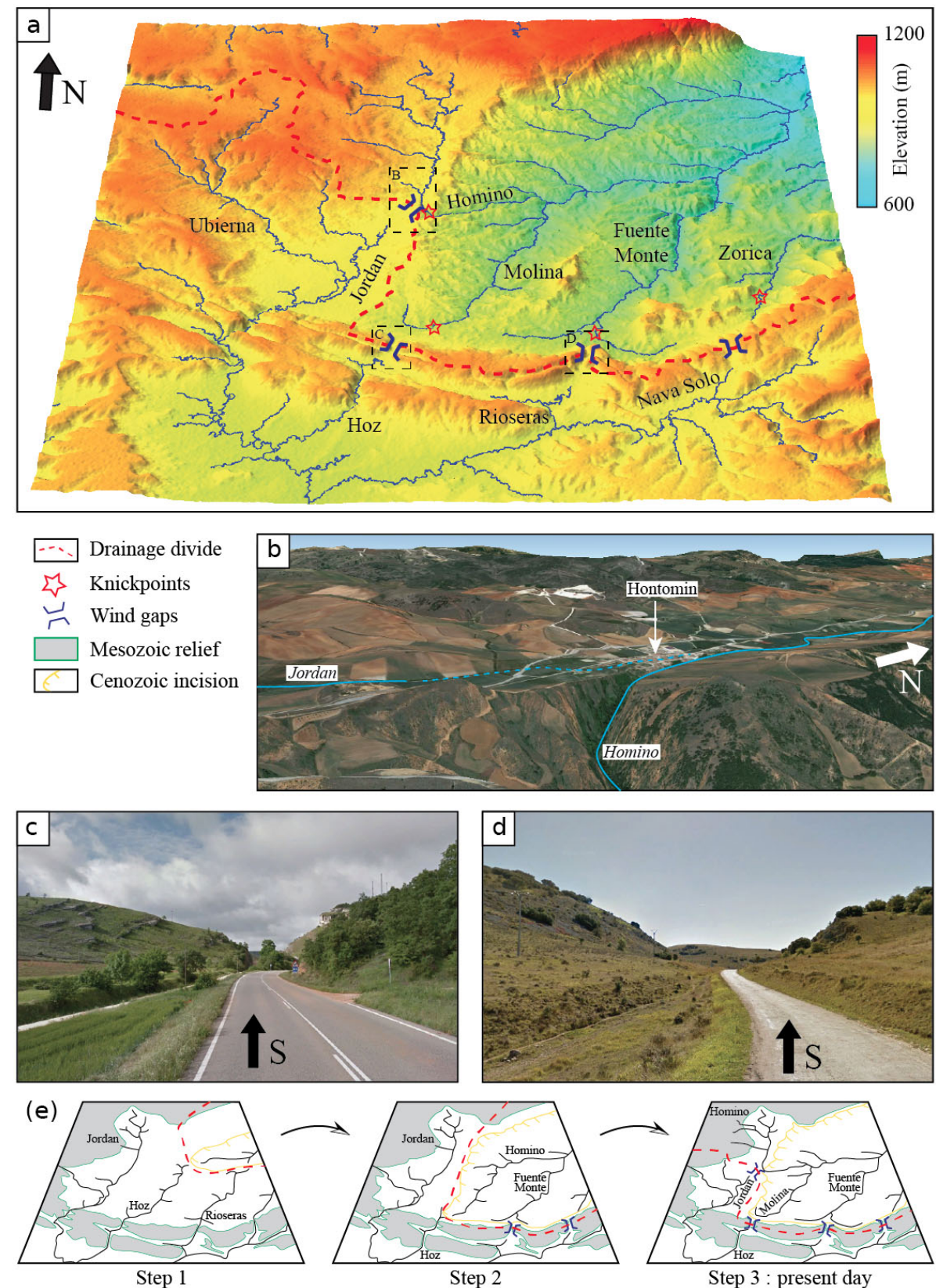

Figure 7. (a) Three-dimensional view of the DEM of the Bureba sector showing important contrast of incision between the Ebro and Duero basins across their divide (red dashed line) and river capture evidence (elbows of capture, knickpoints, and wind gaps). (b) Google Earth image around the locality of Hontomin where the Homino River is capturing the upper reach of the Jordan River. (c, d) Wind gaps cut into the Bureba anticline (see location on a). Pictures have been taken from the north of this structure toward the south. (e) Possible three steps of evolution of the southwestward divide retreat through multiple river captures witnessed in the area.

Incision in the Ebro basin leads to the capture of new drainage areas, whereas the Duero basin recorded important loss of its own surface. The present-day drainage area of the Cenozoic Duero basin, upstream of the major knickzone observed to the west in the Iberian Massif, is $\sim 63000 \mathrm{~km}^{2}$. We used the paleo-divide position shown in Fig. 9 to define a "recent" captured area that used to belong to the Duero basin. This area represents $\sim 7700 \mathrm{~km}^{2}$, which corresponds to $\sim 12 \%$ of the present-day Cenozoic Duero basin drainage area. Such a reduction of the drainage area could have strong implications on the evolution of the Duero basin, as important lowering of water and sediment fluxes, and so of incision throughout the basin. To better resolve the impact of such drainage area reduction on incision capacity, we per- 


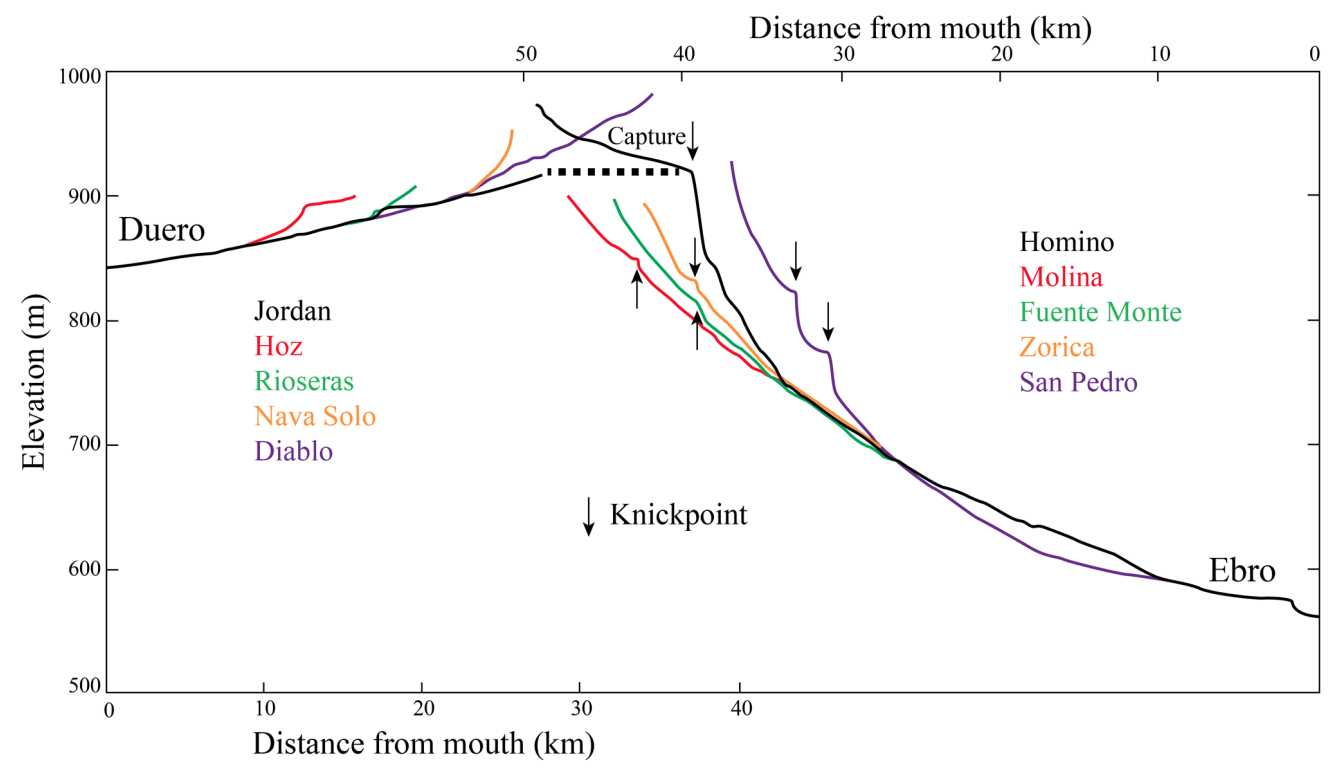

Figure 8. River long profiles for all the streams described in the Bureba area showing evidence of river capture. Colors are given to rivers that are linked in these capture processes.

form a stream power analysis of the Duero River. We consider the specific stream power, $\omega$, defined as $\omega=\rho g Q S / W$, where $\rho$ is water density, $g$ is gravitational acceleration, $Q$ is discharge, $S$ is local river gradient, and $W$ is river width (see the Supplement for details of the calculation). We calculate $\omega$ for the present-day Duero River, and for a restored ancient Duero River that drained this $12 \%$ of lost area. We plot the difference (ancient minus present day) between the two curves in Fig. 10, with the Duero River long profile. Calculated difference in specific stream power values are relatively low $\left(<2 \mathrm{~W} \mathrm{~m}^{-2}\right)$ for the upstream part of the basin, but increase to $\sim 5 \mathrm{~W} \mathrm{~m}^{-2}$ when approaching the major knickzone at a distance of $\sim 350 \mathrm{~km}$ from the river mouth. The knickzone is characterized by peak values exceeding $10 \mathrm{~W} \mathrm{~m}^{-2}$, which rapidly decrease to $\sim 0 \mathrm{~W} \mathrm{~m}^{-2}$ at the base of the knickzone $(\sim 200 \mathrm{~km})$ and up to the river mouth (Fig. 10). Some alternating peak and null values are observed in the lower reach of the river and may be related to the occurrence of numerous dams along the river. Overall, the specific stream power calculated for the ancient Duero River shows higher values than for the present day from the base of the knickzone to the uppermost reach of the river (Fig. 10). This implies a general decrease in the Duero River's incision capacity between this ancient state to the present day, magnified on the knickzone.

\section{$3.4 \chi$ map}

The comparison of the shape of longitudinal profiles of rivers across divide is a way to infer disequilibrium between rivers and the potential migration of their divide that has been proposed recently (Willett et al., 2014). The $\chi$ analysis of river profiles (Perron and Royden, 2012) is a powerful tool to evidence differences in the equilibrium state of rivers across divide, and then to infer their migration (Willett et al., 2014). This method is based on a coordinate transformation allowing linearizing river profiles (Perron and Royden, 2012). Considering constant uplift rate $(U)$ and erodibility $(K)$ in time and space, the $\chi$-transformed profile of a river is defined by the following equation (Perron and Royden, 2012; Mudd et al., 2014):

$z(x)=z_{\mathrm{b}}\left(x_{\mathrm{b}}\right)+\left(\frac{U}{K A_{0}^{m}}\right)^{1 / n} \chi$

with

$\chi=\int_{x_{\mathrm{b}}}^{x}\left(\frac{A_{0}}{A(x)}\right)^{\frac{m}{n}} \mathrm{~d} x$,

where $z(x)$ is the elevation of the channel, $x$ is the longitudinal distance, $z_{\mathrm{b}}$ is the elevation at the river's base level (distance $\left.x_{\mathrm{b}}\right), A$ is the drainage area, $A_{0}$ is a reference drainage area, and exponents $m$ and $n$ are empirical constants.

When using the $\chi$ variable instead of the distance for plotting the elevation $z$ along channel ( $\chi$ plot), the longitudinal profile of a steady-state channel is shown as a straight line (Perron and Royden, 2012). Any channel pulled away from this line is in disequilibrium and is then expected to attempt to reach equilibrium. Mapping $\chi$ on several watersheds and comparing $\chi$ across drainage divides is then a potential way to high disequilibrium among rivers across divide and to elucidate divide migration and drainage reorganization through captures (Willett et al., 2014). 


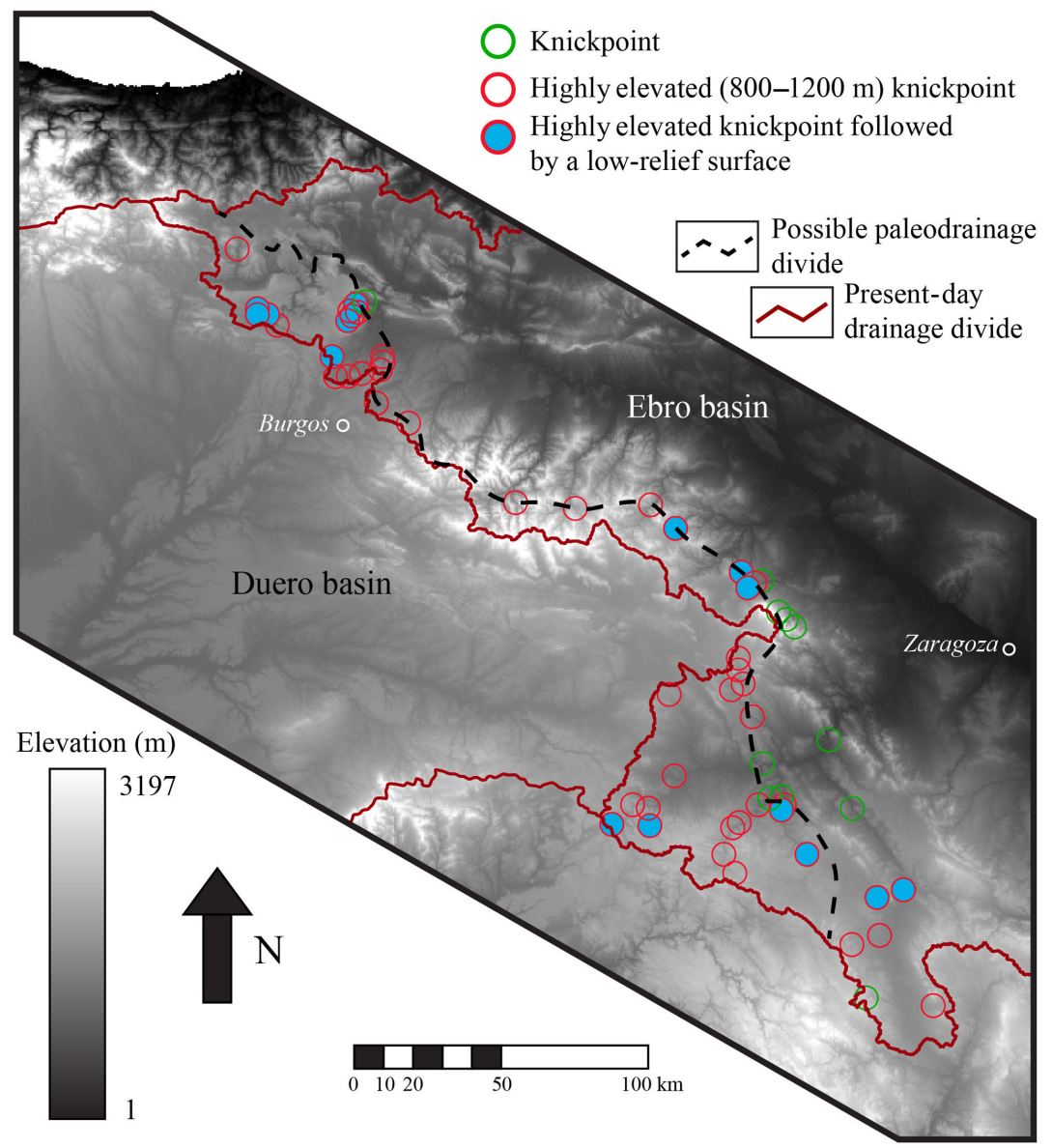

Figure 9. Topographic map showing the location of all the knickpoints and low-relief surfaces that may be associated with river capture. The black dashed line represents a possible paleodrainage divide between the Ebro and Duero basins. The area between this dashed line and the present-day location of the divide in red may have belonged to the Duero basin before being captured by the Ebro basin.

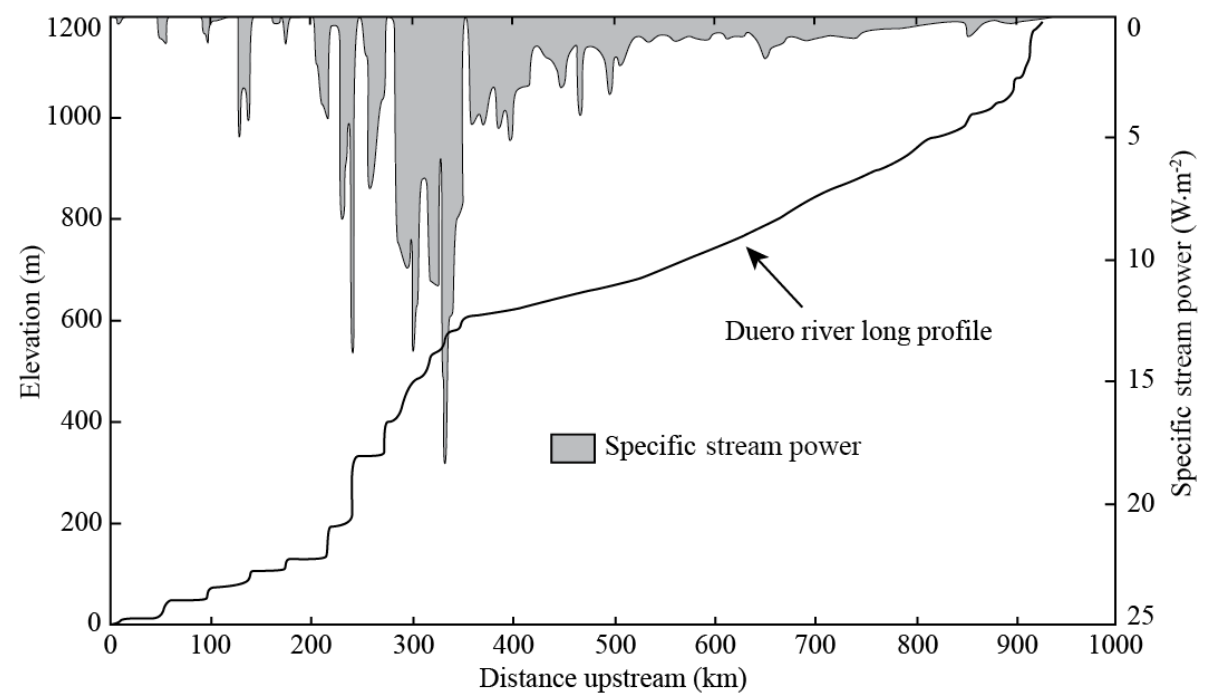

Figure 10. Duero River long profile (black line) and difference in the specific stream power of the river (grey) calculated by considering the paleo and present-day position of its divide. Positive values suggest a significant diminution of the incision capacity of the Duero River, particularly along the knickzone of its longitudinal profile. Details on calculation are available in the Supplement (Sect. S1). 


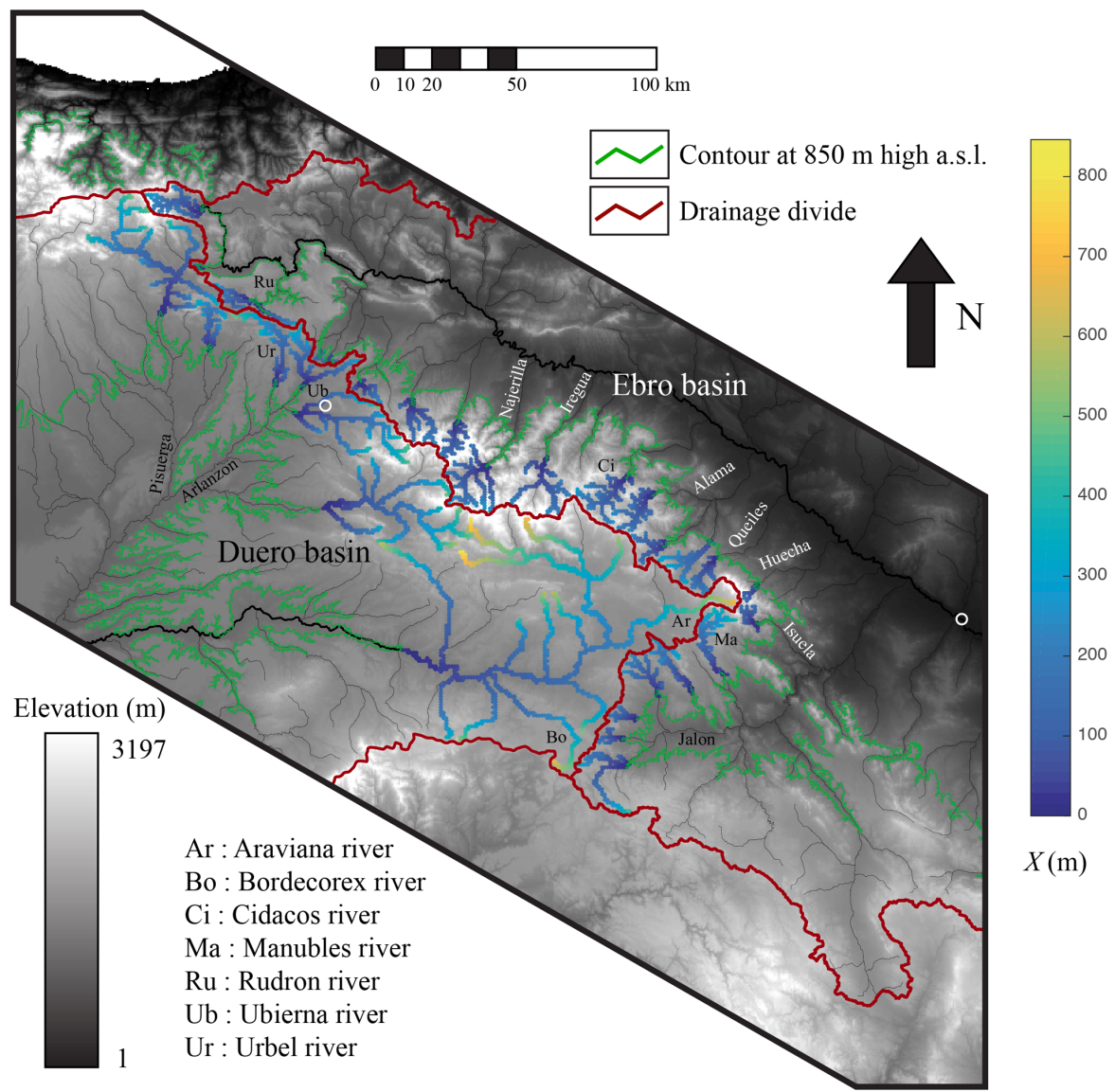

Figure 11. Topographic map with $\chi$ values calculated on different opposite streams in the vicinity of the Ebro-Duero drainage divide. This map shows significant contrasting values between the Ebro and Duero drainage networks.

We used the $\chi$-analysis tool developed by Mudd et al. (2014) to select the best $m / n$ ratio by iteration (Perron and Royden, 2012) and to calculate $\chi$ for rivers throughout the divide between the Ebro and Duero basins from a similar base level at $850 \mathrm{~m}$ a.s.l. The best mean $m / n$ ratio for all our streams is 0.425 , which falls in the typical range of values observed for rivers ( 0.4-0.6; e.g., Kirby and Whipple, 2012). The resulting map (Fig. 11) shows $\chi$ values calculated on different opposite streams in the vicinity of the Ebro-Duero drainage divide. Similar values on both sides of the divide suggest the two opposite streams are at equilibrium, whereas strong contrasted $\chi$ values imply disequilibrium leading to divide migration, continuously or through fluvial capture, toward the high $\chi$ values (Willett et al., 2014). The map of $\chi$ values actually shows significant contrasting values across the Ebro-Duero divide. Here we comment on these contrasts along the divide from the SE to the NW of the area considered (Fig. 11).

There is a strong contrast in $\chi$ values between the headwater of the Jalón River (Fig. 11), characterized by low values $(\sim 300 \mathrm{~m})$, and the closest part from the divide of the Bordecorex River (Fig. 4), a tributary of the Duero River $(\sim 500 \mathrm{~m})$. Such a disequilibrium implies divide migration toward the Duero basin, predicting the capture of the uppermost reach of the Bordecorex River by the Jalón River. To the north, tributaries of the Jalón River show slightly lower $\chi$ values than the tributaries of the Duero River. This suggests a relatively stable situation, although small captures may occur toward the Duero basin. A higher contrast is observed around the easternmost part of the Duero basin, which is surrounded by the Ebro basin. The Araviana River (tributary of the Duero River) seems to be taken in a bottleneck between the Manubles River to the south and the Queiles River to the north (Fig. 4), which show both lower $\chi$ values (Fig. 11). Toward the east, there is a contrast of strongest $\chi$ values among headwaters of the Araviana River ( $>700 \mathrm{~m}$ ) and of the Isuela (Jalón tributary) and Huecha rivers $(<100 \mathrm{~m})$. This domain appears clearly in disequilibrium and is expected to be captured by the Ebro drainage network. Such high $\chi$ value differences also appear to the northwest (Fig. 11), in the southern part of the Cameros basin where the Duero River and its tributaries' headwaters show $\chi$ values $>500-700 \mathrm{~m}$, whereas the facing rivers (Alama, Cidacos, Iregua, and $\mathrm{Na}$ jerilla) are all characterized by low $\chi$ values $<100 \mathrm{~m}$. This 
predicts important disequilibrium and divide migration and fluvial captures toward the south. Northwestward, $\chi$ values between the Duero and Ebro networks are more similar, indicating that the divide is relatively more stable here, up to the westernmost part of the Ebro basin (Fig. 11). However, there are some slight localized $\chi$ value contrasts $(\sim 200$ and $\sim 450 \mathrm{~m}$ ) as observed between the Tirón and the Arlanzón rivers, between the Rudrón and the Ubierna and Úrbel rivers, and between the Ebro and the Pisuerga rivers (Fig. 11). It suggests minor local captures toward the Duero basin.

To sum up, $\chi$ values calculated in the vicinity of the drainage divide between the Ebro and Duero river networks show a general disequilibrium (Fig. 11) as the Ebro network is characterized by low $\chi$ values (up to $\sim 200-300 \mathrm{~m}$ ) compared to those for the Duero network (up to $\sim 450-700 \mathrm{~m}$ ). In complement with all the evidence of divide displacements induced by captures described previously, this allows the prediction of a general divide migration toward the Duero basin through headwater retreat, in favor of the Ebro tributaries, especially around the Almazán subbasin, which is expected to be entirely captured by the Ebro basin.

\section{Discussion}

\subsection{Long-term trend of divide migration}

The oldest capture evidence in our study area corresponds to the incision of the northern part of the Iberian Range by the Jalon River and by the capture of the Calatayud basin, attributed to the post-Messinian (Gutiérrez-Santolalla et al., 1996). We propose, based on morphological evidence (Fig. 4) and in agreement with stratigraphic data (GutiérrezSantolalla et al., 1996), that the Jalón river system captured the Jiloca graben to the east since the Early Pleistocene, before progressively capturing the Almazán subbasin toward the west in the Holocene (Gutiérrez-Santolalla et al., 1996). From $\chi$ analysis (Fig. 11), we deduce that the eastern part of the Duero basin, the Almazán subbasin, is being actively captured by Ebro tributaries that drained the Iberian Range and the Cameros basin. Despite low contrasts in $\chi$ values, local captures are also suggested in the vicinity of the EbroDuero drainage divide toward the northwest. Capture is further implied by the occurrence of numerous highly elevated $(\sim 1000 \mathrm{~m})$ knickpoints and low-relief surfaces (Figs. 5, 8, 9, and 11).

Thus, there is a good correlation between $\chi$ evidence and morphological and stratigraphic data implying long-lasting captures and divide migration during Pliocene, Pleistocene, and Holocene times in favor of the Ebro basin.

The pursuit of such a long-term capture trend may be driven by tectonic and/or climatic forcing (Willett, 1999; Montgomery et al., 2001; Sobel et al., 2003; Sobel and Strecker, 2003; Bonnet, 2009; Whipple, 2009; Castelltort et al., 2012; Kirby and Whipple, 2012; Goren et al., 2015; Van der Beek et al., 2016). However, such a long-term trend in drainage reorganization may also occur in tectonically quiescent domains, independent of external forcing (Prince et al., 2011). Here, the Iberian Range and the Cameros basin recorded extension pulses from the late Miocene to the Early Pleistocene, responsible for the formation of several grabens as previously described (Gutiérrez-Santolalla et al., 1996; Capote et al., 2002). Extension events are also recorded during the Holocene; nevertheless, the youngest erosion surface of late Pliocene-Early Pleistocene age observed in our study area shows no tectonic-related deformation and reworking, suggesting that tectonic activity is reduced here (GutiérrezElorza and Gracia, 1997). This is also consistent with the relative scarcity of seismic activity observed in our study area, compared, for instance, to the Pyrenees, or to the Betics (Herraiz et al., 2000; Lacan and Ortuño, 2012). We consequently propose that local tectonic activity is not the main driver of the capture histories documented here, as most capture events postdate the cessation of tectonic activity and occur during periods of quiescence (Gutiérrez-Santolalla et al., 1996).

The Cameros Massif is characterized by relatively high mean annual precipitation up to $\sim 1000 \mathrm{mman}^{-1}$ (Fig. 6) with high elevation $(\sim 1400-2200 \mathrm{~m})$ in comparison with the surrounding areas. This contrasts with the adjacent Ebro and Duero basins where low precipitation rates, of $\sim 400$ $500 \mathrm{~mm} \mathrm{an}^{-1}$ (Hijmans et al., 2005), illustrate subarid climate conditions. The Cameros area is the only place in our study area where a contrast in precipitation pattern (Fig. 6) would potentially drive a migration of the divide toward the drier, Duero area. Given that the same pattern is observed everywhere, even where there is not any precipitation difference, we suggest that the present-day climatic condition is unlikely to control the general pattern of current drainage reorganization between the Ebro and Duero basins. During the Pliocene and the Pleistocene, the climatic record in the northern Iberia Peninsula is characterized by alternations between similar subarid conditions and intense glaciation. Paleoclimate proxies do not allow us to highlight past precipitation differences along the divide that could explain past drainage reorganization. Moreover, there is no clear evidence of important glacier development and related erosion in our study area, especially for the Cameros basin and the Iberian Range (Ortigosa, 1994; García-Ruiz et al., 1998, 2016; Pellicer and Echeverría, 2004). This indicates that drainage evolution between the Ebro and Duero basins is unlikely to be related to climatic evolution.

\subsection{Excavation of the Ebro basin as the main factor controlling divide migration and limiting incision of the Duero River}

A striking morphological feature for river capture in our study area is the important contrast in the incision pattern (e.g., Fig. 1b) from one side of the divide to the other. This suggests that the incision capacity of the river network is the main driver for capture and divide migration. Both tectonic 
and climatic forcing does not appear to control drainage reorganization between the Ebro and Duero basins.

The opening of the Ebro basin toward the Mediterranean Sea during the late Miocene led to widespread excavation (Garcia-Castellanos et al., 2003; Garcia-Castellanos and Larrasoaña, 2015), favored by more humid and seasonal climatic conditions (Calvo et al., 1993; Alonso-Zarza and Calvo, 2000). By contrast, incision related to the opening of the Duero basin toward the Atlantic Ocean is concentrated to the west in the Iberian Massif, characterized by a large-scale knickzone ( $150 \mathrm{~km}$ long and $500 \mathrm{~m}$ high) in the Duero River long profile (Fig. 1b). This contrasts with the limited eastward propagation of incision in the Cenozoic part of the basin (Antón et al., 2012, 2014), despite climatic conditions similar to the Ebro basin. An explanation resides in the fact that the resistant Iberian Massif basement rocks may have controlled and limited incision and drainage reorganization in the Cenozoic Duero basin (Antón et al., 2012). The Duero profile upstream of this major knickzone may be considered as a highly elevated local base level for its tributaries there. The difference between the Ebro and Duero base levels implies a major contrast in fluvial dynamics. We suggest that the systematic and long-term trend of divide migration toward the Duero basin and fluvial capture in favor of the Ebro basin is driven by the differential incision behavior, controlled by base-level difference.

Our stream power analysis along the Duero River (Fig. 10) shows that the difference in drainage area of the Duero inferred from our paleo-divide map (Fig. 9) induces a noticeable decrease in stream power values of the Duero in the vicinity of the knickzone. This stream power is a minimum estimate because calculation does not take into account possible captures and divide migration in other areas along the Duero basin divide, nor the full history of the divide migration through time and the related ongoing decrease in water discharge as documented in laboratory-scale landscape experiments (Bonnet, 2009). Some contrasts of incision are also observed in the Iberian Range along the southern border of the Duero, and in the Cantabrian domain to the north. Both show more important incision than in the Duero basin, suggesting potential river captures and divide migration at the expense of the Duero basin, increasing the total of lost drainage area. Even if it gives a minimal estimate, our stream power analysis suggests that drainage area reduction may have limited the erosion in the Duero basin. This provides an explanation for the preservation of the lithologic barrier to the west, along the main knickzone of the Duero considered as an intermediate, local base level (Antón et al., 2012).We propose that the reduction of the Duero drainage area caused by captures and incision in the Ebro basin is responsible for a significant decrease in the incision capacity in the Duero basin. We infer that the ongoing drainage network growth in the Ebro basin may be responsible for the current preservation of large morphological relicts of the endorheic stage in the Duero basin.
The opening of the Ebro basin toward the Mediterranean Sea resulted in a drastic base level drop. This results in the establishment of an upstream-migrating incision wave that propagates to every tributary of the Ebro network, responsible for knickpoint migration (Schumm et al., 1987; Whipple and Tucker, 1999; Yanites et al., 2013) and for drainage reorganization and divide migration. The $\chi$ analysis that we performed along the current Ebro-Duero divide (Fig. 11) highlights areas where geomorphic disequilibrium is still ongoing, which suggests that they are areas where divide is currently mobile. The modeling study performed by Garcia-Castellanos and Larrasoaña (2015) suggests that the re-opening of the Ebro basin occurred between 12.0 and 7.5 Ma. This indicates that the growth of the drainage network of the Ebro basin and the establishment of new steadystate conditions is a long-lived phenomenon, which is still not achieved today.

\section{Conclusions}

In this paper we present a morphometric analysis of the landscape along the divide between the Ebro and Duero drainage basins located in the northern part of the Iberian Peninsula. This area shows abundant evidence of river captures by the Ebro drainage network resulting in a long-lasting migration of their divide toward the Duero basin. Although these two basins record a similar geological history, with a long endorheic stage during Oligocene and Miocene times, they show a very contrasted incision and preservation state of their original endorheic morphology. Since the late Miocene, the Ebro basin has been opened to the Mediterranean Sea and recorded important erosion. In contrast, the Duero has been opened to the Atlantic Ocean since the late Miocene-Early Pliocene but its longitudinal profile exhibits a pronounced knickpoint, which delimits an upstream domain of low relief and limited incision, likely representing a relict of its endorheic topography. We propose that this contrast of incision is the main driver of the migration of divide that we document. The morphological analysis of rivers across the divide highlights areas where geomorphic disequilibrium is still ongoing, which suggests that the Ebro-Duero divide is currently mobile. The quantification of the decrease in the drainage area of the Duero based on the reconstruction of a paleo-position of the Ebro-Duero divide shows that the divide migration results in a significant lowering of the stream power of the Duero River, particularly along its knickzone. We suggest that divide migration induces a decrease in the incision capacity of the Duero River, thus favoring the preservation of large relicts of the endorheic morphology in the upstream part of this basin.

Data availability. No data sets were used in this article. 


\section{The Supplement related to this article is available online at https://doi.org/10.5194/esurf-6-369-2018-supplement.}

Author contributions. AV undertook morphometric modeling and interpretation, and wrote the paper. SB and FM contributed to the interpretation and the writing.

Competing interests. The authors declare that they have no conflict of interest.

Acknowledgements. This study was funded by the OROGEN project, a TOTAL-BRGM-CNRS consortium. We thank the two reviewers and associated editor Veerle Vanacker for very useful and constructive comments that greatly helped us to clarify and improve this paper.

Edited by: Veerle Vanacker

Reviewed by: two anonymous referees

\section{References}

Alonso-Zarza, A. M. and Calvo, J. P.: Palustrine sedimentation in an episodically subsiding basin: the Miocene of the northern Teruel Graben (Spain), Palaeogeogr. Palaeocl., 160, 1-21, 2000.

Alonso-Zarza, A. M., Armenteros, I., Braga, J. C., Muñoz, A., Pujalte, V., Ramos, E., Aguirre, J., Alonso-Gavilán, G., Arenas, C., Ignacio Baceta, J., Carballeira, J., Calvo, J. P., Corrochano, A., Fornós, J. J., González, A., Luzón, A., Martín, J. M., Pardo, G., Payros, A., Pérez, A., Pomar, L., Rodriguez, J. M., and Villena, J.: Tertiary, in: The Geology of Spain, edited by: Gibbons, W. and Moreno, T., The Geological Society, London, pp. 293-334, 2002.

Antón, L., Rodés, A., De Vicente, G., Pallàs, R., GarciaCastellanos, D., Stuart, F. M., Braucher, R., and Bourlès, D.: Quantification of fluvial incision in the Duero Basin (NW Iberia) from longitudinal profile analysis and terrestrial cosmogenic nuclide concentrations, Geomorphology, 165-166, 50-61, https://doi.org/10.1016/j.geomorph.2011.12.036, 2012.

Antón, L., Rodés, A., De Vicente, G., and Stokes, M.: Using river long profiles and geomorphic indices to evaluate the geomorphological signature of continental scale drainage capture, Duero basin (NW Iberia), Geomorphology, 206, 250-261, https://doi.org/10.1016/j.geomorph.2013.09.028, 2014.

Babault, J., Loget, N., Van Den Driessche, J., Castelltort, S., Bonnet, S., and Davy, P.: Did the Ebro basin connect to the Mediterranean before the Messinian salinity crisis?, Geomorphology, 81, 155-165, https://doi.org/10.1016/j.geomorph.2006.04.004, 2006.

Barrón, E., Postigo-Mijarra, J. M., and Casas-Gallego, M.: Late Miocene vegetation and climate of the La Cerdanya Basin (eastern Pyrenees, Spain), Rev. Palaeobot. Palyno., 235, 99-119, https://doi.org/10.1016/j.revpalbo.2016.08.007, 2016.

Bartolomé, M., Sancho, C., Moreno, A., Oliva-Urcia, B., Belmonte, Á., Bastida, J., Cheng, H., and Edwards, R. L.: Upper Pleistocene interstratal piping-cave speleogenesis: The Seso Cave System (Central Pyrenees, Northern Spain), Geomorphology, 228, 335344, https://doi.org/10.1016/j.geomorph.2014.09.007, 2015.

Bessais, E. and Cravatte, J.: Les écosystèmes végétaux Pliocènes de Catalogne Méridionale. Variations latitudinales dans le domaine Nord-Ouest Méditerranéen, Geobios, 21, 49-63, 1988.

Bond, J.: Tectono-sedimentary evolution of the Almazan Basin, NE Spain, in: Tertiary Basins of Spain: the Stratigraphic Record of Crustal Kinematics, edited by: Friend, F. and Dabrio, C., World and Regional Geology, vol. 6, Cambridge University Press, Cambridge, 203-213, 1996.

Bonnet, S.: Shrinking and splitting of drainage basins in orogenic landscapes from the migration of the main drainage divide, Nat. Geosci., 90, 766-771, https://doi.org/10.1038/NGEO666, 2009.

Brocklehurst, S. H. and Whipple, K. X.: Glacial erosion and relief production in the Eastern Sierra Nevada, California, Geomorphology, 42, 1-24, 2002.

Calvo, J. P., Daams, R., and Morales, J.: Up-to-date Spanish continental Neogene synthesis and paleoclimatic interpretation, Revista de la Sociedad Geologica de España, 6, 29-40, 1993.

Cameselle, A. J., Urgeles, R., De Mol, B., Camerlenghi, A., and Canning, J. C., Late Miocene sedimentary architecture of the Ebro Continental Margin (Western Mediterranean; Implications for the Messinian Salinity Crisis, Int. J. Earth Sci., 103, 423-440, 2014.

Capote, R., Muñoz, J. A., Simón, J. L., Liesa, C. L., and Arlegui, L. E.: Alpine tectonics 1: the Alpine system north of the Betic Cordillera, in: The Geology of Spain, edited by: Gibbons, W. and Moreno, T., The Geological Society, London, pp. 367-400, 2002.

Castelltort, S., Goren, L., Willett, S. D., Champagnac, J. D., Herman, F., and Braun, J.: River drainage patterns in the New Zealand Alps primarily controlled by plate tectonic strain, Nat. Geosci., 5, 744-748, https://doi.org/10.1038/ngeo1582, 2012.

Colomer i Busquets, M. and Santanach i Prat, P.: Estructura y evolucion del borde sur-occidental de la Fosa de Calatayud-Daroca, Geogaceta, 4, 29-31, 1988.

Coney, P. J., Muñoz, J. A., McClay, K. R., and Evenchick, C. A.: Syntectonic burial and post-tectonic exhumation of the southern Pyrenees foreland fold-thrust belt, J. Geol. Soc. London, 153, 916, https://doi.org/10.1144/gsjgs.153.1.0009, 1996.

Costa, E., Garcés, M., López-Blanco, M., Beamud, E., GómezPaccard, M., and Larrasoaña, J. C.: Closing and continentalization of the South Pyrenean foreland basin (NE Spain): magnetochronological constraints, Basin Res., 22, 904-917, https://doi.org/10.1111/j.1365-2117.2009.00452.x, 2010.

Delmas, M., Calvet, M., and Gunnel, Y.: Variability of Quaternary glacial erosion rates - A global perspective with special reference to the Eastern Pyrenees, Quaternary Sci. Rev., 28, 484-498, https://doi.org/10.1016/j.quascirev.2008.11.006, 2009.

Del Rio, P., Barbero, L., and Stuart, F. M.: Exhumation of the Sierra de Cameros (Iberian Range, Spain): constraints from low-temperature thermochronologie, in: Thermochronological Methods: From Palaeotemperature Constraints to Landscape Evolution Models, edited by: Liesker, F., Ventura, B., and Glasmacher, U. A., Geol. Soc. Spec. Publ., 324, 154-166, https://doi.org/10.1144/SP324.12, 2009.

De Vicente, G., Vegas, R., Muñoz, M. A., Silva, P. G., Andriessen, P., Cloetingh, S., González-Casado, J. M., Van 
Wees, J. D., Álvarez, J., Carbó, A., and Olaiz, A.: Cenozoic thick-skinned deformation and topography evolution of the Spanish Central System, Global Planet. Change, 58, 335-381, https://doi.org/10.1016/j.gloplacha.2006.11.042, 2007.

Duval, M., Sancho, C., Calle, M., Guilarte, V., and PeñaMonné, J. L.: On the interest of using the multiple center approach in ESR dating of optically bleached quartz grains: Some examples from the Early Pleistocene terraces of the Alcanadre River (Ebro basin, Spain), Quat. Geochronol., 29, 58-69, https://doi.org/10.1016/j.quageo.2015.06.006, 2015.

Fillon, C. and Van der Beek, P.: Post-orogenic evolution of the southern Pyrenees: contraints from inverse thermokinematic modelling of low-temperature thermochronology data, Basin Res., 23, 1-19, https://doi.org/10.1111/j.13652117.2011.00533.x, 2012.

Fillon, C., Gautheron, C., and Van der Beek, P.: Oligocene-Miocene burial and exhumation of the Southern Pyrenean foreland quantified by low-temperature thermochronology, J. Geol. Soc. London, 170, 67-77, https://doi.org/10.1144/jgs2012-051, 2013.

Garcia-Castellanos, D.: Long-term evolution of tectonic lakes: Climatic controls on the development of internally drained basins, Geol. Soc. Am. Spec. Paper, 398, 283-294, https://doi.org/10.1130/2006.2398(17), 2006.

Garcia-Castellanos, D. and Larrasoaña, J. C.: Quantifying the post-tectonic topographic evolution of closed basins: The Ebro basin (northeast Iberia), Geology, 43, 663-666, https://doi.org/10.1130/G36673.1, 2015.

Garcia-Castellanos, D., Vergés, J., Gaspar-Escribano, J., and Cloething, S.: Interplay between tectonics, climate, and fluvial transport during the Cenozoic evolution of the Ebro Basin (NE Iberia), J. Geophys. Res., 108, 2347, https://doi.org/10.1029/2002JB002073, 2003.

García-Ruiz, J. M., Ortigosa, L. M., Pellicer, F., and Arnáez, J.: Geomorfologia glaciar del Sistema Ibérico, in: Las huellas glaciares de las montañas españolas, edited by: Gómez-Ortiz, A. and Pérez-Alberti, A., Universidad de Santiago de Compostela, Santiago de Compostela, pp. 347-381, 1998.

García-Ruiz, J. M., Palacios, D., González-Sampériz, P., De Andrés, N., Moreno, A., Valero-Garcés, B., and Gómez-Villar, A.: Mountain glacier evolution in the Iberian Peninsula during the Younger Dryas, Quaternary Sci. Rev., 138, 16-30, https://doi.org/10.1016/j.quascirev.2016.02.022, 2016.

Goren, L., Castelltort, S., and Klinger, Y.: Modes and rates of horizontal deformation from rotated river basins: Application to the Dead Sea fault system in Lebanon, Geology, 43, 843-846, https://doi.org/10.1130/G36841.1, 2015.

Gracia, F. J.: Tectonica pliocena de la Fosa de Daroca (prov. De Zaragoza), Geogaceta, 11, 127-129, 1992.

Gracia, F. J.: Evolucion cuaternaria del rio Jiloca (Cordillera Iberica Central), in: Estudios sobre Cuaternario, Medios Sedimentarios, Cambios Ambientales, edited by: Fumanal, M. P. and Bernabeu, J. Habitat Humano, Valencia, pp. 43-51, $1993 \mathrm{a}$.

Gracia, F. J.: Evolucion geomorfologica de la region de Gallocanta (Cordillera Iberica Central), Geographicalia, 30, 3-17, 1993b.

Gracia, F. J. and Cuchi, J. A.: Control tectonico de los travertinos fluviales del rio Jiloca (Cordillera Ibérica), in: El Cuaternario en España y Portugal, Actas 2a Reun. Cuat. Ibérico, AEQUA y CTPEQ, Madrid-1989, 2, 697-706, 1993.
Gracia, F. J., Gutiérrez-Santolalla, F., and Gutiérrez-Elorza, M.: Evolucion geomorfologica del polje de Gallocanta (Cordillera Ibérica), Revista Sociedad Geologica de España, 12, 351-368, 1999.

Guimerà, J., Mas, R., and Alonso, Á: Intraplate deformation in the NW Iberian Chain: Mesozoic extension and Tertiary contractional inversion, J. Geol. Soc. London, 161, 291-303, https://doi.org/10.1144/0016-764903-055, 2004.

Gutiérrez-Elorza, M. and Gracia, F. J.: Environmental interpretation and evolution of the Tertiary erosion surfaces in the Iberian Range (Spain), in: Palaeosurfaces: Recognition, Reconstruction and Palaeoenvironmental Interpretation, edited by: Widdowson, M., Geol. Soc. Spec. Publ., 120, 147-158, 1997.

Gutiérrez-Elorza, M., García-Ruiz, J. M., Goy, J. L., Gracia, F. J., Gutiérrez-Santolalla, F., Martí, C., Martín-Serrano, A., PérezGonzález, A., and Zazo, C.: Quaternary, in: The Geology of Spain, edited by: Gibbons, W. and Moreno, T., The Geological Society, London, 335-366, 2002.

Gutiérrez-Santolalla, F., Gracia, F. J., and Gutiérrez-Elorza, M.: Consideraciones sobre el final del relleno endorreico de las fossa de Calatayud y Teruel y su paso al exorreismo. Implicaciones morfoestratigraficas y estructurales, in: IV Reunion de Geomorfologia, edited by: Grandal d'Ánglade, A., and PagésValcarlos, J., Sociedad Española de Geomorfologia, O Castro (A Coruña), pp. 23-43, 1996.

Herraiz, M., De Vicente, G., Lindo-Ñaupari, R., Giner, J., Simón, J. L., González-Casado, J. M., Vadillo, O., RodríguezPascua, M. A., Cicuéndez, J. I., Casas, A., Cabañas, L., Rincón, P., Cortés, A. L., Ramírez, M., and Lucini, M.: Tectonics, 19, 762-786, 2000.

Hijmans, R. J., Cameron, S. E., Parra, J. L., Jones, P. G., and Jarvis, A.: Very high resolution interpolated climate surfaces for global land areas, Int. J. Climatol., 25, 1965-1978, https://doi.org/10.1002/joc.1276, 2005.

Jiménez-Moreno, G., Fauquette, S., and Suc, J. P.: Miocene to Pliocene vegetation reconstruction and climate estimates in the Iberian Peninsula from pollen data, Rev. Palaeobot. Palyno., 162, 403-415, https://doi.org/10.1016/j.revpalbo.2009.08.001, 2010.

Jiménez-Moreno, G., Burjachs, F., Expósito, I., Oms, O., Carrancho, Á., Villalaín, J. J., Agustí, J., Campeny, G., Gómez de Soler, B., and Van der Made, J.: Late Pliocene vegetation and orbital-scale climate changes from the western Mediterranean area, Global Planet. Change, 108, 15-28, https://doi.org/10.1016/j.gloplacha.2013.05.012, 2013.

Jurado, M. J. and Riba, O.: The Rioja area (westernmost Ebro basin): a ramp valley with neighbouring piggybacks, in: Tertiary basins of Spain, edited by: Friend, P. and Dabrio, C., World and Regional Geology, vol. 6, Cambridge University Press, Cambridge, 173-179, 1996 .

Kirby, E. and Whipple, K. X.: Expression of active tectonics in erosional landscapes, J. Struct. Geol., 44, 54-75, https://doi.org/10.1016/j.jsg.2012.07.009, 2012.

Kuhlemann, J., Frisch, W., Dunkl, I., Székely, D., and Spiegel, C.: Miocene shifts of the drainage divide in the Alps and their foreland basin, Z. Geomorphol., 45, 239-265, 2001.

Lacan, P. and Ortuño, M.: Active tectonics of the Pyrenees: a review, J. Iberian Geol., 38, 9-30, https://doi.org/10.5209/rev_JIGE.2012.v38.n1.39203, 2012. 
Larrasoaña, J. C., Murelaga, X., and Garcés, M.: Magnetobiochronology of Lower Miocene (Ramblian) continental sediments from the Tuleda Formation (western Ebro basin, Spain), Earth Planet. Sc. Lett., 243, 409-423, https://doi.org/10.1016/j.epsl.2006.01.034, 2006.

López-Blanco, M., Marzo, M., Burbank, D. W., Vergés, J., Roca, E., Anadón, P., and Piña, J.: Tectonic and climatic controls on the development of foreland fan deltas: Montserrat and Sant Llorenç del Munt systems (Middle Eocene, Ebro Basin, NE Spain), Sediment. Geol., 138, 17-39, 2000.

López-Martínez, N., García-Moreno, E., and Álvarez-Sierra, A.: Paleontologia y bioestratigrafia (micromamiferos) del Mioceno medio y superior del sector central de la cuenca del Duero, Studia Geologica Salmanticensia, Ediciones Universidad Salamanca, 22, 191-212, 1986.

Martín-Chivelet, J., Berástegui, X., Rosales, I., Vilas, L., Vera, J. A., Caus, E., Gräfe, K. U., Mas, R., Puig, C., Segura, M., Robles, S., Floquet, M., Quesada, S., Ruiz-Ortiz, P. A., FregenalMartínez, M. A., Salas, R., Arias, C., García, A., MartínAlgarra, A., Meléndez, M. N., Chacón, B., Molina, J. M., Sanz, J. L., Castro, J. M., García-Hernández, M., Carenas, B., García-Hidalgo, J., Gil, J., and Ortega, F.: Cretaceous, in: The Geology of Spain, edited by: Gibbons, W. and Moreno, T., The Geological Society, London, pp. 255-292, 2002.

Martín-Serrano, A.: La definicion y el encajamiento de la red fluvial actual sobre el macizo hesperico en el marco de su geodinamica alpina, Rev. Soc. Geol. España, 4, 337-351, 1991.

Mikeš, D.: The Upper Cenozoic evolution of the Duero and Ebro fluvial systems (N-Spain): Part 1. Paleogeography; Part 2. Geomorphology, Cent. Eur. J. Geosci., 2, 320-332, https://doi.org/10.2478/v10085-010-0017-4, 2010.

Montgomery, D. R., Balco, G., and Willett, S. D.: Climate, tectonics, and the morphology of the Andes, Geology, 29, 579-582, 2001.

Moreno, D., Falguères, C., Pérez-González, A., Duval, M., Voinchet, P., Benito-Calvo, A., Ortega, A. I., Bahain, J. J., Sala, R., Carbonell, E., Bermúdez de Castro, J. M., and Arsuaga, J. L.: ESR chronology of alluvial deposits in the Arlanzon valley (Atapuerca, Spain): Contemporaneity with Atapuerca Gran Dolina site, Quat. Geochronol., 10, 418-423, https://doi.org/10.1016/j.quageo.2012.04.018, 2012.

Moreno, D., Belmonte, A., Bartolomé, M., Sancho, C., Oliva, C., Stoll, H., Edwards, L. R., Cheng, H., and Hellstrom, J.: Formacion de espeleotemas en el noreste peninsular y su relacion con las condiciones climaticas durante los ultimos ciclos glaciares, Cuadern. Investig. Geografica, 39, 25-47, 2013.

Mudd, S., Attal, M., Milodowski, D. T., Grieve, S. W. D., and Valters, D. A.: A statistical framework to quantify spatial variation in channel gradients using the integral method of channel profile analysis, J. Geophys. Res.-Earth, 119, 138-152, https://doi.org/10.1002/2013JF002981, 2014.

Muñoz-Jiménez, A. and Casas-Sainz, A. M.: The Rioja Trough (N Spain): tectonosedimentary evolution of a symmetric foreland basin, Basin Res., 9, 65-85, 1997.

Nivière, B., Lacan, P., Regard, V., Delmas, M., Calvet, M., Huyghe, D., and Roddaz, B.: Evolution of the Late Pleistocene Aspe River (Western Pyrenees, France). Signature of climatic events and active tectonics, C. R. Geosci., 348, 203-212, https://doi.org/10.1016/j.crte.2015.07.003, 2016.
Ortigosa, L. M.: Las grandes unidades des relieve, Geografia de la Rioja, 1, 62-71, 1994.

Palacios, D., De Marcos, J., and Vásquez-Selem, L.: Last Glacial Maximum and deglaciation of the Sierra de Gredos, central Iberian Peninsula, Quatern. Int., 233, 16-26, https://doi.org/10.1016/j.quaint.2010.04.029, 2011.

Palacios, D., Andrés, N., De Marcos, J., and Vásquez-Selem, L.: Maximum glacial advance and deglaciation of the Pinar Valley (Sierra de Gredos, Central Spain) and its significance in the Mediterranean context, Geomorphology, 177-178, 51-61, https://doi.org/10.1016/j.geomorph.2012.07.013, 2012.

Pellicer, F. and Echeverría, M. T.: El modelado glaciar y periglaciar en el macizo del moncayo, in: Geografia Fisica de Aragon, Aspetos generals y tematicos, edited by: Peña, J. L., Longares, L. A., and Sánchez, M., Universidad de Zaragoza e Institucion Fernado el Catolico, Zaragoza, pp. 173-185, 2004.

Pérez-Rivarés, F. J., Garcés, M., Arenas, C., and Pardo, G.: Magnetocronologia de la sucesion Miocena de la Sierra de Alcubierre (sector central de la cuenca del Ebro), Rev. Soc. Geol. España, 15, 217-231, 2002.

Pérez-Rivarés, F. J., Garcés, M., Arenas, C., and Pardo, G.: Magnetostratigraphy of the Miocene continental deposits of the Montes de Castejon (central Ebro basin, Spain): geochronological and paleoenvironmental implications, Geol. Acta, 2, 221-234, 2004.

Perron, J. T. and Royden, L.: An integral approach to bedrock river profile analysis. Earth Surf. Proc. Land., 38, 570-576, https://doi.org/10.1002/esp.3302, 2012.

Pineda Velasco, A.: Montorio. Mapa geologico de España; escala 1 : 50.000; Segunda serie, Instituto Geologico y Minero de España (IGME), Madrid, 110 pp., 1997.

Prince, P. S., Spotila, J. A., and Henika, W. S.: Stream capture as driver of transient landscape evolution in a tectonically quiescent setting, Geology, 39, 823-826, https://doi.org/10.1130/G32008.1, 2011.

Puigdefàbregas, C., Muñoz, J. A., and Vergés, J.: Thrusting and foreland basin evolution in the Southern Pyrenees, in: Thrust Tectonics, edited by: McClay, K. R., Chapman \& Hall, London, pp. 247-254, 1992.

Pulgar, J. A., Alonso, J. L., Espina, R. G., and Marín, J. A.: La deformacion alpine en el basamento varisco de la Zona Cantabrica, Trabajos de Geologia, University of Oviedo, 283-294, 1999.

Riba, O., Reguant, S., and Villena, J.: Ensayo de sintesis estratigrafica y evolutiva de la Cuenca terciaria del Ebro, in: Geologia de España, 2, Libro Jubila J. M. Rios, edited by: Comba, J. A., Instituto Geologico y Minero de España, Madrid, pp. 131-159, 1983.

Rivas-Carballo, M. R., Alonso-Gavilán, G., Valle, M. F., and Civis, J.: Miocene Palynology of the central sector of the Duero Basin (Spain) in relation to palaeogeography and palaeoenvironment, Rev. Palaeobot. Palyno., 82, 251-264, 1994.

Salas, R., Guimerà, J., Mas, R., Martín-Closas, C., Meléndez, A., and Alonso, A.: Evolution of the Mesozoic Central Iberian Rift System and its Cainozoic inversion (Iberian Chain), in: PeriTethys Memoir 6: Peri-Tethyan Rift/Wrench Basins and Passive Margins, edited by: Ziegler, P. A., Cavazza, W., Robertson, A. F. H., and Crasquin-Soleau, S., Mémoires du Muséum national d'Histoire naturelle, 186, 145-185, 2001.

Sancho, C., Calle, M., Peña-Monné, J. L., Duval, M., OlivaUrcia, B., Pueyo, E. L., Benito, G., and Moreno, A.: Dat- 
ing the Earliest Pleistocene alluvial terrace of the Alcanadre River (Ebro Basin, NE Spain): Insights into the landscape evolution and involved processes, Quatern. Int., 407, 86-95, https://doi.org/10.1016/j.quaint.2015.10.050, 2016.

Schumm, S. A., Mosley, M. P., and Weaver, W. E.: Experimental fluvial geomorphology, John Wiley and Sons, New York, 413 pp., 1987.

Schwanghart, W. and Scherler, D.: Short Communication: TopoToolbox 2 - MATLAB-based software for topographic analysis and modeling in Earth surface sciences, Earth Surf. Dynam., 2, 1-7, https://doi.org/10.5194/esurf-2-1-2014, 2014.

Serrano, E., González-Trueba, J. J., Pellitero, R., GonzálezGarcía, M., and Gómez-Lende, M.: Quaternary glacial evolution in the Central Cantabrian Mountains (Northern Spain), Geomorphology, 196, 65-82, https://doi.org/10.1016/j.geomorph.2012.05.001, 2013.

Serrano, E., González-Trueba, J. J., Pellitero, R., and GómezLende, M.: Quaternary glacial history of the Cantabrian Mountains of northern Spain: a new synthesis, in: Quaternary Glaciation in the Mediterranean Mountains, edited by: Hughes, P. D. and Woodward, J. C., Geol. Soc. Spec. Publ., 433, 55, https://doi.org/10.1144/SP433.8, 2016.

Sobel, E. R. and Strecker, M. R.: Uplift, exhumation and precipitation: tectonic and climatic control of Late Cenozoic landscape evolution in the northern Sierras Pampeanas, Argentina, Basin Res., 15, 431-451, https://doi.org/10.1046/j.13652117.2003.00214.x, 2003.

Sobel, E. R., Hilley, G. E., and Strecker, M. R.: Formation of internally drained contractional basins by ariditylimited bedrock incision, J. Geophys. Res., 108, 2344, https://doi.org/10.1029/2002JB001883, 2003.

Stange, K. M., Van Balen, R. T., Garcia-Castellanos, D., and Cloething, S.: Numerical modelling of Quaternary terrace staircase formation in the Ebro foreland basin, southern Pyrenees, NE Iberia, Basin Res., 1-23, https://doi.org/10.1111/bre.12103, 2014.

Suc, J. P. and Popescu, S. M.: Pollen records and climatic cycles in the Mediterranean region since 2.7 Ma, in: Early-Middle Pleistocene Transitions, the Land-Ocean Evidence, edited by: Head, M. J. and Gibbard, P. L., Geol. Soc. Spec. Publ., 247, 147158, https://doi.org/10.1144/GSL.SP.2005.247.01.08, 2005.

Urgeles, R., Camerlenghi, A., Garcia-Castellanos, D., De Mol, B., Garcés, M., Vergés, J., Haslam, I., and Hardman, M.: New constraints on the Messinian sealevel drawdown from 3D seismic data of the Ebro Margin, western Mediterranean, Basin Res., 23, 123-145, https://doi.org/10.1111/j.1365-2117.2010.00477.x, 2010 .
Van der Beek, P., Litty, C., Baudin, M., Mercier, J., Robert, X., and Hardwick, E.: Contrasting tectonically driven exhumation and incision patterns, Western versus central Nepal Himalaya, Geology, 44, 327-330, https://doi.org/10.1130/G37579.1, 2016.

Vázquez-Urbez, M., Arenas, C., Pardo, G., and Pérez-Rivarés, J.: The effect of drainage reorganization and climate on the sedimentologic evolution of intermontane lake systems: the final fill stage of the Tertiary Ebro Basin (Spain), J. Sediment. Res., 83, 562-590, https://doi.org/10.2110/jsr.2013.47, 2013.

Villena, J., Pardo, G., Pérez, A., Muñoz, A., and González, A.: The Tertiary of the Iberian margin of the Ebro basin: palaeogeography and tectonic control, in: Tertiary basins of Spain, edited by: Friend, P. and Dabrio, C., World and Regional Geology, vol. 6, Cambridge University Press, Cambridge, 83-88, 1996.

Whipple, K.: The influence of climate on the tectonic evolution of mountain belts, Nat. Geosci., 2, 97-104, https://doi.org/10.1038/ngeo638, 2009.

Whipple, K. X. and Tucker, G. E.: Dynamics of the stream-power river incision model: Implications for height limits of mountain ranges, landscape response timescales, and research needs, J. Geophys. Res., 104, 17661-17674, 1999.

Whipple, K. X., Forte, A. M., DiBiase, R. A., Gasparini, N. M., and Ouimet, W. B.: Timescales of landscape response to divide migration and drainage capture: implications for the role of divide mobility in landscape evolution, J. Geophys. Res.-Earth, 122, 248-273, https://doi.org/10.1002/2016JF003973, 2017.

Whitfield, E. and Harvey, A. M.: Interaction between the controls on fluvial system development: tectonics, climate, base level and river capture - Rio Alias, Southeast Spain, Earth Surf. Proc. Land., 37, 1387-1397, https://doi.org/10.1002/esp.3247, 2012.

Willett, S. D.: Orogeny and orography: The effects of erosion on the structure of mountain belts, J. Geophys. Res., 104, 28957-28981, 1999.

Willett, S. D., McCoy, S. W., Perron, J. T., Goren, L., and Chen, C. Y.: Dynamic reorganization of river basins, Science, 343, 1248765, https://doi.org/10.1126/science.1248765, 2014.

Yanites, B. J., Elhers, T. A., Becker, J. K., Schnellmann, M., and Heuberger, S.: High magnitude and rapid incision from river capture: Rhine River, Switzerland, J. Geophys. Res.-Earth, 118, 1060-1084, https://doi.org/10.1002/jgrf.20056, 2013. 